\title{
Akt Regulates Axon Wrapping and Myelin Sheath Thickness in the PNS
}

\author{
Enric Domènech-Estévez, ${ }^{1,2,3 *}$ Hasna Baloui, ${ }^{1,2,3 *}$ Xiaosong Meng, ${ }^{1,2}$ Yanqing Zhang, ${ }^{1,2}$ (-Katrin Deinhardt, ${ }^{4}$ \\ 엉f L. Dupree, ${ }^{5}$ Steven Einheber, ${ }^{6}$ Roman Chrast, ${ }^{3}$ and James L. Salzer ${ }^{1,2}$ \\ ${ }^{1}$ Neuroscience Institute and ${ }^{2}$ Departments of Neuroscience and Physiology and Neurology, New York University-Langone Medical Center, New York, \\ New York 10016, ${ }^{3}$ Departments of Neuroscience and Clinical Neuroscience, Karolinska Institutet, Stockholm 17177, Sweden, ${ }^{4}$ Centre for Biological \\ Sciences, Faculty of Natural and Environmental Sciences, University of Southampton, Southampton S017 1BJ, United Kingdom, ${ }^{5}$ Department of Anatomy

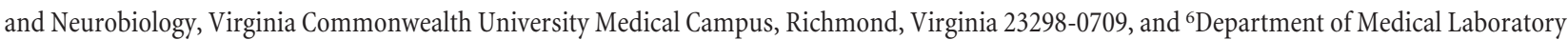 \\ Sciences, Hunter College, City University of New York, New York, New York 10010
}

The signaling pathways that regulate myelination in the PNS remain poorly understood. Phosphatidylinositol-4,5-bisphosphate 3-kinase $1 \mathrm{~A}$, activated in Schwann cells by neuregulin and the extracellular matrix, has an essential role in the early events of myelination. Akt/PKB, a key effector of phosphatidylinositol-4,5-bisphosphate 3-kinase 1A, was previously implicated in CNS, but not PNS myelination. Here we demonstrate that Akt plays a crucial role in axon ensheathment and in the regulation of myelin sheath thickness in the PNS. Pharmacological inhibition of Akt in DRG neuron-Schwann cell cocultures dramatically decreased MBP and P0 levels and myelin sheath formation without affecting expression of Krox20/Egr2, a key transcriptional regulator of myelination. Conversely, expression of an activated form of Akt in purified Schwann cells increased expression of myelin proteins, but not Krox20/Egr2, and the levels of activated Rac1. Transgenic mice expressing a membrane-targeted, activated form of Akt under control of the $2^{\prime}, 3^{\prime}$-cyclic nucleotide $3^{\prime}$ phosphodiesterase promoter, exhibited thicker PNS and CNS myelin sheaths, and PNS myelin abnormalities, such as tomacula and myelin infoldings/outfoldings, centered around the paranodes and Schmidt Lanterman incisures. These effects were corrected by rapamycin treatment in vivo. Importantly, Akt activity in the transgenic mice did not induce myelination of nonmyelinating Schwann cells in the sympathetic trunk or Remak fibers of the dorsal roots, although, in those structures, they wrapped membranes redundantly around axons. Together, our data indicate that Akt is crucial for PNS myelination driving axonal wrapping by unmyelinated and myelinated Schwann cells and enhancing myelin protein synthesis in myelinating Schwann cells.

Key words: Akt; mTOR; myelin; Schwann cell; transgenic; wrapping

Significance Statement

Although the role of the key serine/threonine kinase Akt in promoting CNS myelination has been demonstrated, its role in the PNS has not been established and remains uncertain. This work reveals that Akt controls several key steps of the PNS myelination. First, its activity promotes membrane production and axonal wrapping independent of a transcriptional effect. In myelinated axons, it also enhances myelin thickness through the mTOR pathway. Finally, sustained Akt activation in Schwann cells leads to hypermyelination/dysmyelination, mimicking some features present in neuropathies, such as hereditary neuropathy with liability to pressure palsies or demyelinating forms of Charcot-Marie-Tooth disease. Together, these data demonstrate the role of Akt in regulatory mechanisms underlying axonal wrapping and myelination in the PNS.

\section{Introduction}

Formation of the myelin sheath in the PNS is among the most dramatic examples of axon-glial interactions (Mirsky et al., 2008). Schwann cells are intimately associated with axons and adopt distinct fates as either myelinating or nonmyelinating (i.e., Remak Schwann cells). These two Schwann cell phenotypes are distinguished by both their morphological relationship with the axon and different transcriptional profiles. A number of axonal 
signals have been implicated in the regulation of the Schwann cell phenotype, including ADAM22, which binds Lgi4 secreted by the Schwann cell and the axonal growth factor neuregulin1 Type III (Nrg1III), which activates the ErbB2/ErbB3 heterodimer on Schwann cells (for recent reviews, see Kidd et al., 2013; Nave and Werner, 2014; Monk et al., 2015; Salzer, 2015).

Nrg1, in particular, controls virtually all aspects of the Schwann cell lineage, including initial gliogenesis, proliferation, ensheathment, and myelination of axons. High levels of Nrg1III on the axonal membrane provide a threshold signal for the induction of myelination and regulate the thickness of the myelin sheath (Michailov et al., 2004; Taveggia et al., 2005; Nave and Salzer, 2006). Nrg1III activates the mitogen-activated protein kinase (MAPK), phosphatidylinositol-4,5-bisphosphate 3-kinase $1 \mathrm{~A}(\mathrm{PI} 3 \mathrm{~K})$, and phospholipase C gamma (PLC $\gamma$ ) pathways, each of which has been implicated as essential for proper myelination (Newbern and Birchmeier, 2010). The precise roles of these signaling pathways in the transcriptional and morphogenetic events of myelination, however, remain to be established.

Previous studies using in vitro models demonstrated that PI3K activation is necessary for proper PNS myelination (Maurel and Salzer, 2000; Ogata et al., 2004). A promyelinating role of PI3K was further supported by studies in mice in which the phosphatase and tensin homolog (PTEN), a PI3 phosphatase, was conditionally inactivated in glia, thereby driving sustained activation of PI3K (Goebbels et al., 2010). Loss of PTEN function in these mice, as well as inactivation of its interactor Dlg1 (Cotter et al., 2010; Goebbels et al., 2010; Noseda et al., 2013), results in PNS hypermyelination and increased wrapping of small-caliber axons by Schwann cells.

The serine/threonine kinase Akt has been thought to be the major PI3K effector during myelination, particularly in the CNS (Flores et al., 2008). Mice expressing a constitutively active, phospho-mimetic form of Akt under control of the proteolipid protein (PLP) promoter exhibit hypermyelination in the CNS. Surprisingly, the PNS of these mice was not hypermyelinated (Flores et al., 2008), leaving open the question of the role of Akt in Schwann cells.

Here we use loss- and gain-of-function approaches to provide direct evidence that Akt promotes PNS myelination and axonal wrapping. Pharmacological inhibition of Akt activity abrogates myelin formation in vitro, without affecting the levels of Krox20/ Egr2, a transcription factor crucial for PNS myelination (Zorick et al., 1996; Decker et al., 2006). Conversely, mice that express a myristoylated, constitutively active Akt transgene in myelinating glia under control of the $2^{\prime}, 3^{\prime}$-cyclic nucleotide $3^{\prime}$-phosphodiesterase (CNP) promoter exhibit hypermyelination in the PNS and CNS. No conversion of axons from an unmyelinated to a myelinated fate was observed in these mice, although aberrantly, hyperwrapped Remak fibers are common. These mice also exhibit focal hypermyelination, a pathological hallmark of some models of peripheral neuropathies (Adlkofer et al., 1997; Bolino et al., 2004; Tersar et al., 2007; Robinson et al., 2008). They de-

\footnotetext{
(New York University) and Kjell Hultenby and Eva Idsund (Karolinska Institutet) for assistance with EM of mouse neural tissue; Dr. Teresa Milner (Weill Cornell Medical College) for assistance with EM of the cocultures; and Dr. Frédéric Schütz (University of Lausanne) for support with statistics.

The authors declare no competing financial interests.

*E.D.-E. and H.B. contributed equally to this work.

Correspondence should be addressed to either of the following: Dr. Enric Domènech-Estévez, Retzius väg 8 , 17177 Stockholm, Sweden, E-mail: enric.domenech-estevez@ki.se; or Dr. James L. Salzer, 550 First Avenue, New York, NY 10016, E-mail: james.salzer@nyumc.org.

DOI:10.1523/JNEUROSCI.3521-15.2016

Copyright $\odot 2016$ the authors $\quad 0270-6474 / 16 / 364507-16 \$ 15.00 / 0$
}

velop myelin defects similar to those described in a model of tomaculous neuropathy (Goebbels et al., 2012), which can be corrected with rapamycin treatment. Finally, Akt activation in vitro results in activation of Rac1, previously implicated in myelin sheath wrapping (Thurnherr et al., 2006; Benninger et al., 2007; Nodari et al., 2007).

Together, these data indicate that Akt promotes Schwann cell wrapping and myelination via multiple distinct pathways involving $\mathrm{mTOR}$ and Racl activation.

\section{Materials and Methods}

Generation of the CNP-MyrAkt and CNP-AktDD transgenic mice. cDNAs for MyrAktHA and HAAktDD were kindly provided by Dr. Thomas Franke (New York University) (Franke et al., 1995; Matsui et al., 1999). A plasmid containing the CNP promoter (Gravel et al., 1998) was kindly provided by Dr. Karen Chandross (Sanofi).

CNP-MyrAkt. The vector containing the CNP cassette was digested with BamHI and dephosphorylated with CIP phosphatase. MyrAktHA was released using BamHI/BglII digestion and inserted after the CNP promoter. The construct CNP-MyrAktHA was then released by sequential digestion AseI/BtsI. DNA was purified by gel extraction (QIAquick gel extraction, QIAGEN), salt elution (Elutip-D, Whatman \#10462615), and ethanol precipitation.

$C N P-A k t D D$. The vector containing the CNP cassette was digested with AfeI/BamHI. An initial ClaI digestion followed by Kleenow filling was done in AktDD cDNA. Afterward, BamHI digestion was performed. The insert was ligated after the CNP promoter and then released using AseI/MluI digestion. The DNA was purified as described for the CNPMyrAktHA construct.

The constructs were injected into FVB females in the New York University Medical Center Transgenic Mouse Core. Positive founders were PCR identified over tail DNA using the primers TgAkt forward (5' -TCT GAG GAT GCC AAG GAG AT-3') and TgAkt reverse (5'-GGG CGA TCG AGT GAA TTG TA-3'). To ensure the specificity of the PCR product, one of the primers was designed to match a portion of plasmid inserted with the cassette. Founders were backcrossed to C57BL6 wildtype (WT) mice for at least five generations before analysis; sibling littermates were used in all analyses. All experiments were performed with the L1MyrAkt line, but a similar phenotype was observed in the L2MyrAkt line. In some cases (AktDD), analysis was done on founders because of infertility. All experiments with mice were performed in accordance with the legal requirements of New York University.

Akt knock-outs. Akt1KO (Cho et al., 2001a) and Akt2KO (Cho et al., 2001b) were obtained from The Jackson Laboratory (stock \#004912 and \#006966, respectively). Akt3KO (Easton et al., 2005) was obtained from Dr. Morris J. Birnbaum (University of Pennsylvania) under MTA agreement.

Materials. Antibodies to specific proteins were obtained from the following companies: Cell Signaling Technology (total Akt1-3, pAkt Ser473, pAkt Thr308, total c-Jun and p c-Jun Ser73, total S6RP and pS6RP Ser235/236, total GSK3b and pGSK3b Ser9, rabbit HA), Millipore (rabbit MBP, chicken P0, chicken MBP, mouse NeuN), Covance (mouse SMI 94 MBP, chicken Neurofilament), and Sigma (mouse tubulin, rabbit anti-EHS laminin, rabbit actin, mouse HA.11). Rabbit anti-Krox20 and rabbit anti-Oct6 were kindly provided by Dr. Dies Mejer (University of Edinburg), guinea pig anti-CASPR by Dr. M. Bhat (University of North Carolina), and guinea pig anti-Oct6 antibody by Dr. Jeremy Dasen (New York University). Secondary antibodies conjugated to rhodamine, AMCA, or Alexa-488 were obtained from Jackson ImmunoResearch Laboratories.

Immunoblotting. Tissues were lysed in 2\% SDS, $25 \mathrm{~mm}$ Tris, $95 \mathrm{~mm}$ $\mathrm{NaCl}$, and $10 \mathrm{~mm}$ EDTA buffer with protease inhibitors (complete Mini EDTA-free tablets, Roche 11836170001) and phosphatase inhibitors (PhosSTOP, Roche 04906837001). Nerves were sonicated $10 \mathrm{~s}$ at the lowest intensity. A total of $15-50 \mu$ g of protein was loaded on $12.5 \%$ SDS-PAGE gel. After transfer on nitrocellulose membrane (Whatman $\# 10402580$ ) and incubation with primary antibodies, the blots were de- 
A
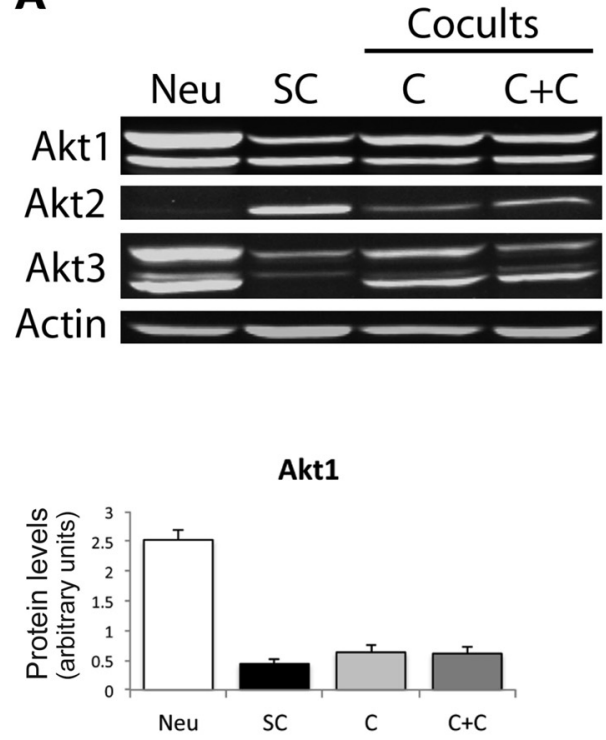

Akt2

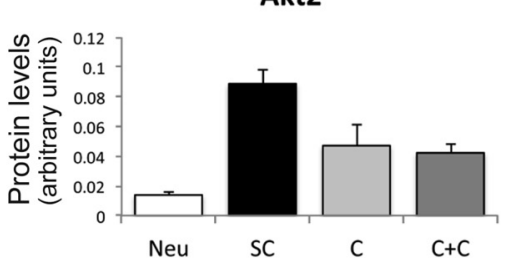

Akt3

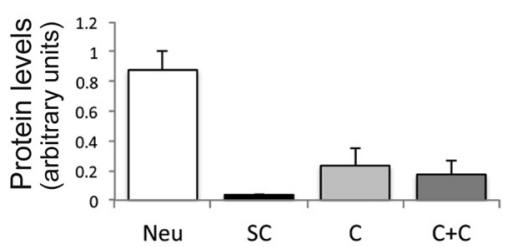

B

WT
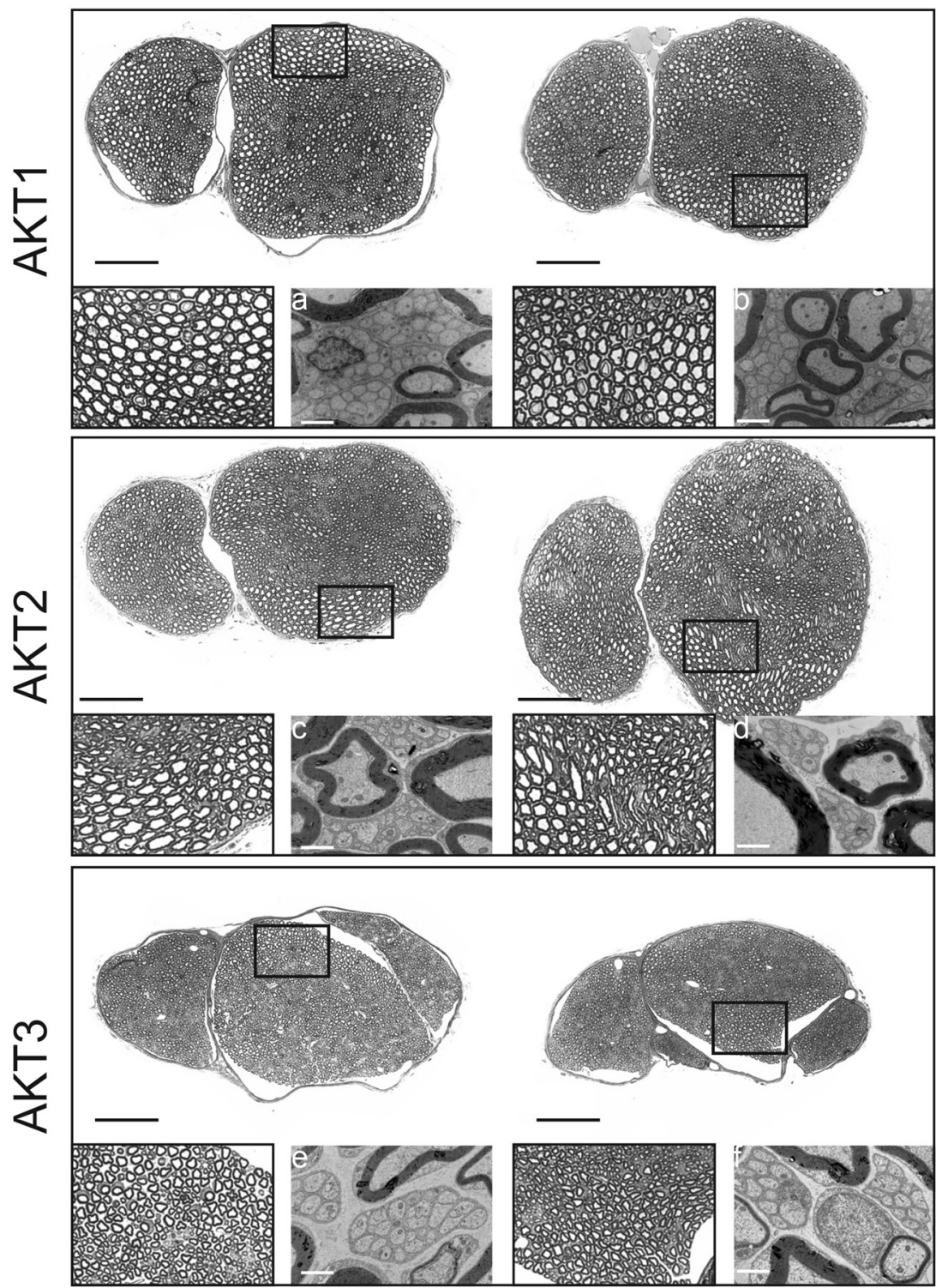

Figure 1. Loss of individual Akt isoforms in vivo does not affect PNS myelination. $A$, Western blot analysis of the expression of the three Akt isoforms in DRG neurons (Neu), Schwann cells (SC), and nonmyelinated $(C)$ or myelinated $(C+C)$ cocultures. Akt1 and Akt3 are preferentially expressed by neurons, whereas Akt2 is primarily expressed by Schwann cells. $n=3$. Data are mean \pm SEM. $B$, Semithin sections of sciatic nerves from 2-month-old mice deficient in each Akt isoform revealed no obvious defects of myelination. Left panels, Magnification of the inset from the semithin section. Right panels $(\boldsymbol{a}-\boldsymbol{f})$, Representative images of Remak bundles. No abnormalities of myelination or ensheathment were evident at the time point analyzed, although no quantifications were performed. Scale bars: semithin, $100 \mu \mathrm{m}$; EM, $2 \mu \mathrm{m}$.

veloped and quantified by using infrared secondary antibodies and software from Odyssey Imager (LI-COR Biosciences).

Lentivirus production and infection. Doxycycline-inducible lentiviruses were created in the pSLIK-Hygromycin vector as per the manufacturer's instructions (Invitrogen, Gateway Technology with clonase II). Confluent 293FT cells were lipofected with LipoD293 reagent (SignaGen Laboratories, SL 100668). A triple lipofection with $\Delta 8.9(4 \mu \mathrm{g})$, VSVG $(6 \mu \mathrm{g})$, and MyrAkt-HA or GFP ( $5 \mu \mathrm{g})$ was performed. Supernatant was collected $48 \mathrm{~h}$ after lipofection and used to infect Schwann cells. Infected cells were selected for $9 \mathrm{~d}$ with $200 \mu \mathrm{g} / \mathrm{ml}$ of hygromycin (Hygrogold, Invivogen \# ant-hg-1) before use in experiments. Induction was performed by adding doxycycline $(2 \mu \mathrm{g} / \mathrm{ml})$ to the culture media for $4 \mathrm{~d}$.

DRG-Schwann cell cocultures. Rat neuron-Schwann cell cocultures were performed as previously described (Taveggia et al., 2005).

Rapamycin and LY294002 (LY) were obtained from LC Laboratories (R-5000 and L-7962, respectively). Perifosine (Pf) was obtained from
Cayman Chemical (10008112). Drugs (20 $\mu \mathrm{M}$ of LY294002 or $20 \mu \mathrm{M}$ of perifosine) were added $24 \mathrm{~h}$ before and then continued after switching the cocultures to myelinating media.

Rac1 and cdc42 pull-down. Schwann cells were infected with inducible MyrAkt and processed as described above. Doxycycline was then added to the proliferative Schwann cell media for $4 \mathrm{~d}$, and Racl and cdc42 activities were analyzed as previously described (Deinhardt et al., 2011). To generate the respective plots, values of active GTPase levels were divided by the total GTPase levels after actin normalization, which was used as a loading control.

Cell culture immunofluorescence and immunohistochemistry. Mice were fixed via transcardial perfusion with $4 \%$ PFA. Dissected brains were postfixed in $4 \%$ PFA overnight at $4^{\circ} \mathrm{C}$, cryoprotected by immersion in $20 \%$ sucrose in PBS; $40 \mu \mathrm{m}$ floating sections were prepared on a cryostat. Cells were fixed $15 \mathrm{~min}$ with $4 \%$ PFA. Tissue and cells were processed for immunostaining as previously described (Zanazzi et al., 2001). For Fig- 
A
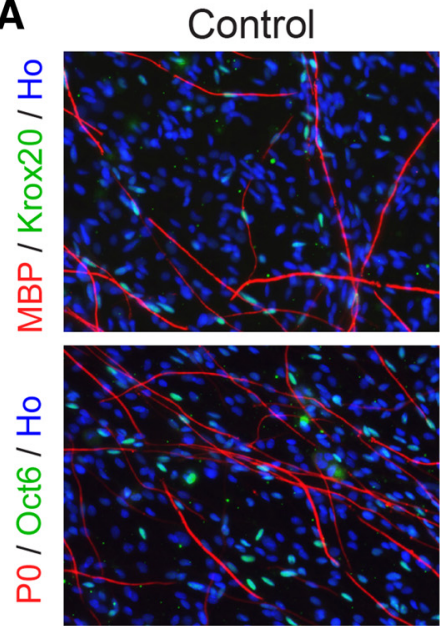

$\mathrm{Pf}$
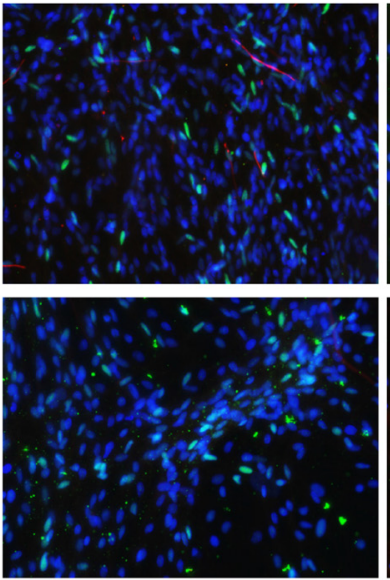

LY
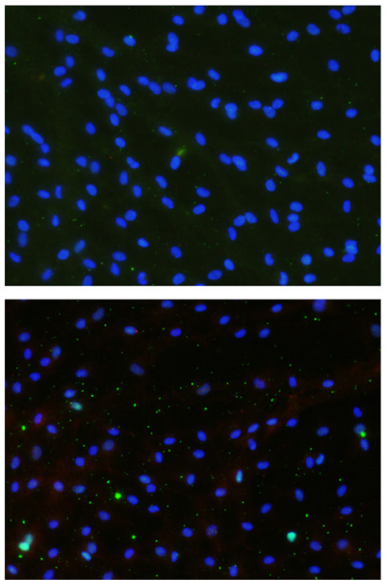

B

number myelin segments

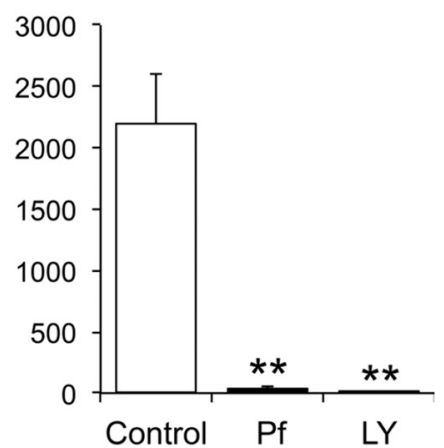

C

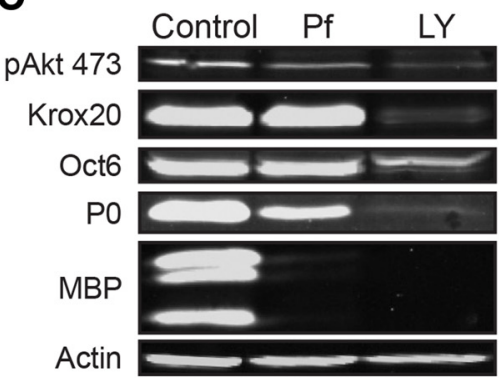

D

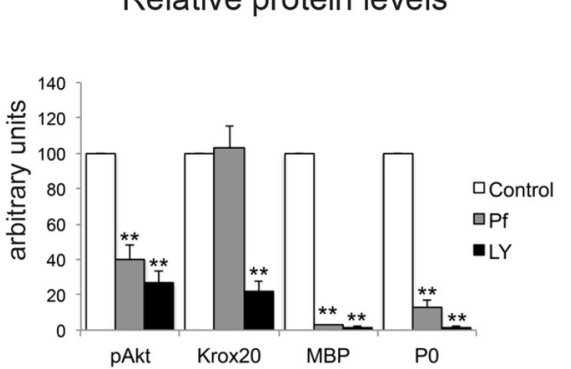

E

Relative mRNA levels

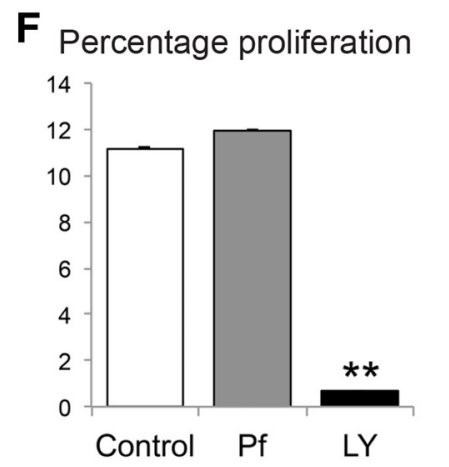

G

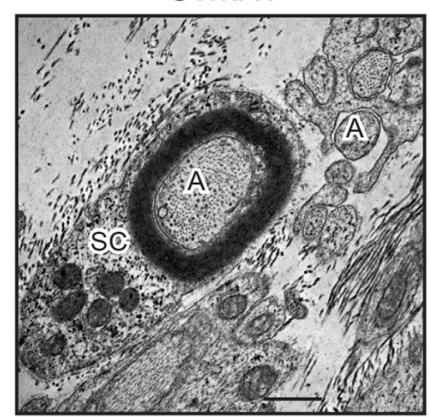

Pf

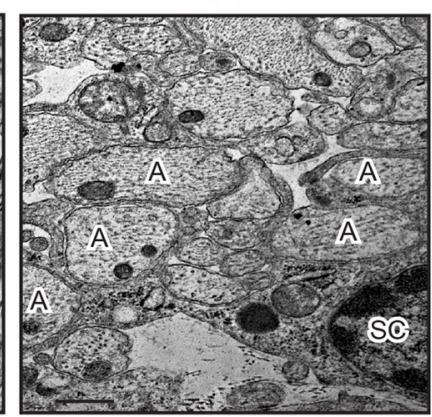

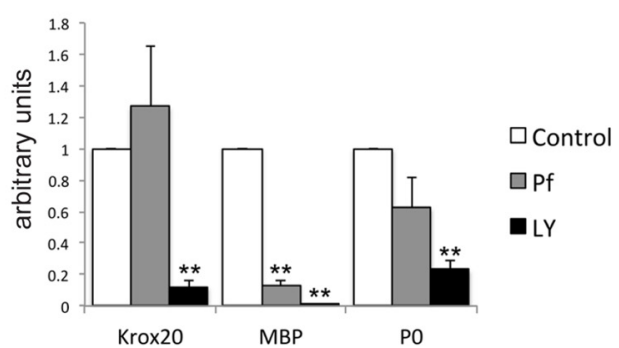

PO

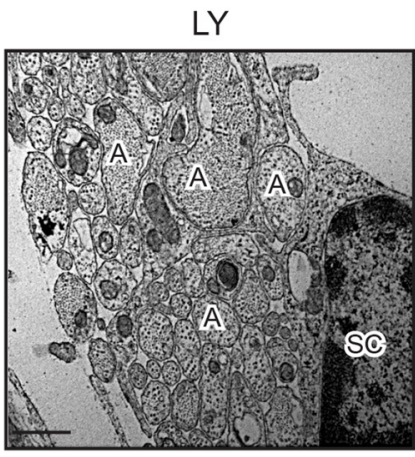

Figure 2. Akt inhibition blocks myelin formation in vitro without affecting Krox20 levels. A, Treatment of DRG neuron-Schwann cell cocultures with perifosine (Pf) or LY294002 (LY) blocked myelination. The myelin transcription factors Krox20 and 0 ct 6 continue to be robustly expressed by Schwann cells in the Pf- but not the LY-treated cocultures. $n=5$; four coverslips were analyzed for each $n$. B, Quantification of the blockade of myelination by Pf and LY. The average number of myelin segments per coverslip were as follows: controls, $2195 ; \mathrm{Pf}, 37$ ( $p=0.0056) ;$ and LY, 3 segments $(p=0.005) . n=3$; each $n$ represents two coverslips. $\boldsymbol{C}, \boldsymbol{D}$, Pf-treated cells showed no change in Krox20 protein expression $(102.8 \pm 12.31, p=0.83)$, although a significant decrease in pAkt $473(40.1 \pm 7.77, p=0.001), \mathrm{MBP}(3.1 \pm 0.2, p<0.001)$, and P0 $(12.5 \pm 4.49, p<0.001)$ was detected. The same markers were also downregulated in LY-treated cocultures (pAkt $26.7 \pm 6.84, p<0.001 ;$ MBP $1.6 \pm 1.03, p<0.001 ; \mathrm{P} 01.69 \pm 0.68, p<0.001)$, but in this case Krox20 was also decreased $(22.1 \pm 5.86, p<0.001)(n=3$, each $n$ represents eight coverslips pooled per condition). Western blot quantification data were normalized using values from control cocultures that were arbitrarily set to 100 . E, As detected by real-time PCR, Pf-treated cells showed no changes in Krox20 mRNA (1.27 $\pm 0.39, p=0.51)$ and a significant decrease of mRNA for MBP $(0.13 \pm 0.03, p<0.001)$. A decrease of P0 was also detected, although it did not reach statistical significance $(0.62 \pm 0.18 p=0.09$ ). These three markers were significantly downregulated in LY-treated cocultures (Krox20 $0.12 \pm 0.04, p<0.001 ; \mathrm{MBP} 0.01 \pm 0.003, p<0.001 ; \mathrm{P} 00.23 \pm$ $0.06, p<0.001$ ). Expression data were normalized to control samples that were arbitrarily set as 1 ; GAPDH expression was used as reference. $n=4$; four coverslips were pooled per condition for each $n . F$, Schwann cell proliferation was not affected by $20 \mu \mathrm{m}$ of Pf $(11.9 \pm 0.019 \mathrm{vs}$ Control $11.2 \pm 0.02)$, whereas proliferation was almost absent with $20 \mu \mathrm{m}$ of $L Y$ treatment $(0.7 \pm 0.002, p=$ 0.003). $n=4$; each $n$ represents three coverslips per condition. G, EM analysis of control, Pf-treated, and LY-treated cultures revealed drug-specific differences. In the presence of Pf, Schwann cells (SC) engaged axons $(\boldsymbol{A})$ and partially but incompletely sorted them and failed to myelinate. LY-treated Schwann cells completely failed to sort axons. Image depicts representative fields from the cultures shown in $\boldsymbol{A}$. Scale bars, $1 \mu \mathrm{m}$. Data are mean \pm SEM. ${ }^{*} p<0.05 ;{ }^{* *} p<0.01$.

ure $4 D$, adult mouse sciatic nerve and DRGs were fixed in $1 \%$ PFA and embedded for cryosectioning and processed for immunofluorescence.

Teased fibers. Sciatic nerves were harvested from 6-month-old animals and fixed in 2\% PFA for $4 \mathrm{~h}$. After a $10 \mathrm{~min}$ wash in $30 \mathrm{~mm}$ glycine PBS, the fibers were teased on a glass slide using needles and dried overnight. Slides were kept at $-80^{\circ} \mathrm{C}$ until needed. Tissue was permeabilized $20 \mathrm{~min}$ in cold methanol before staining as described above. Then, the same protocol as used for cell staining was followed.

Proliferation assay. A total of 50,000 rat Schwann cells were seeded into established, purified rat neuron cultures for $24 \mathrm{~h}$ before adding the drugs ( $\mathrm{Pf}$ and LY) to the media in a final volume of $400 \mu$ l. Twenty-hours later, cocultures were exposed to media containing the drugs and $20 \mu \mathrm{M}$ 
A

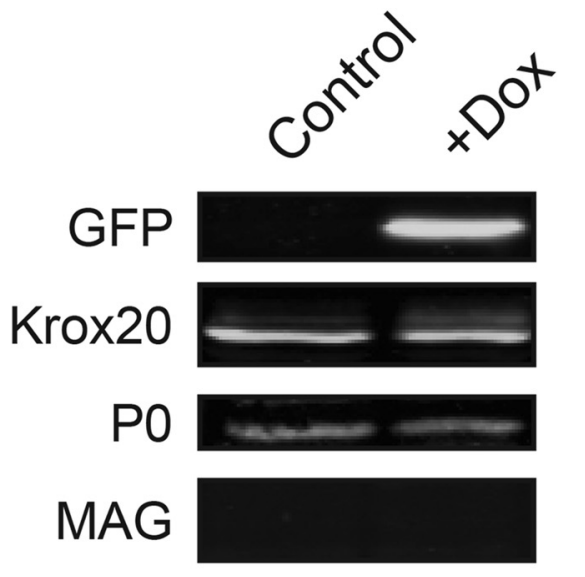

C

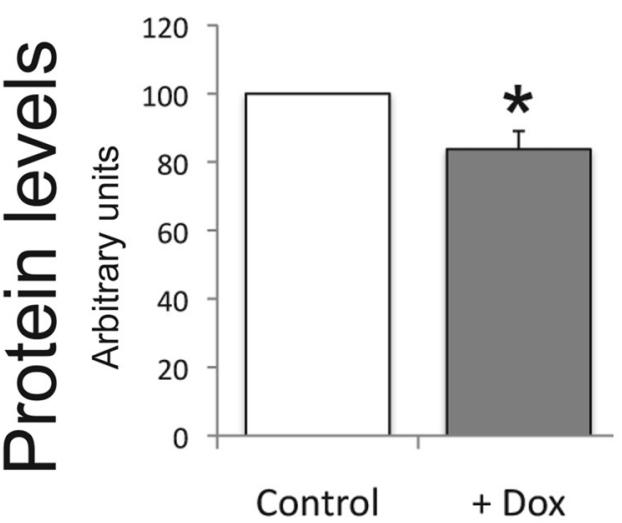

D

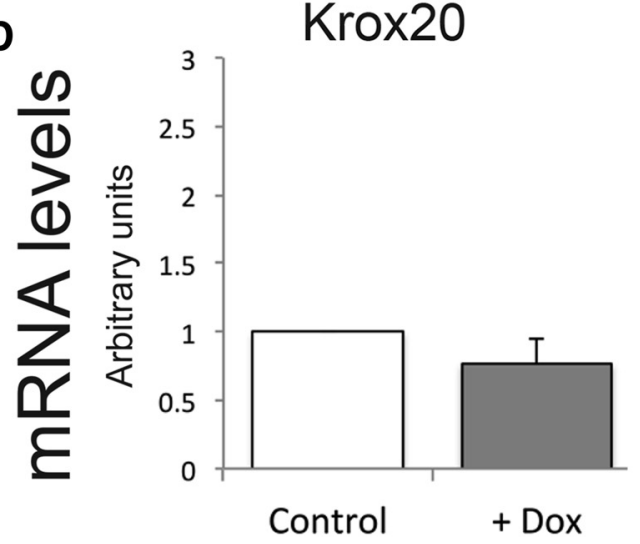

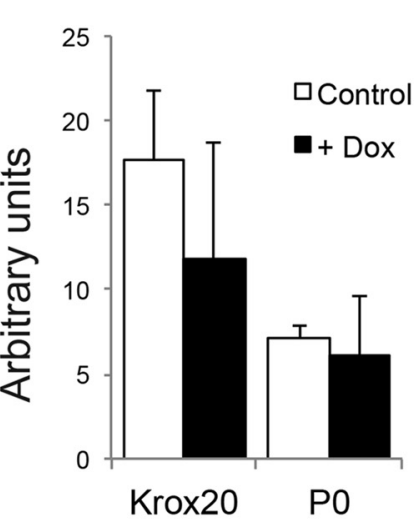

PO

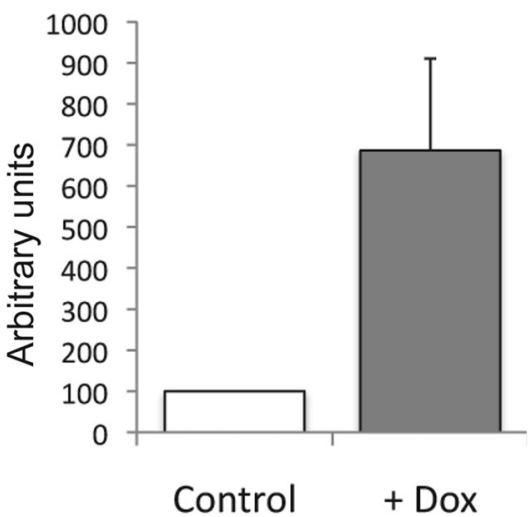

PO

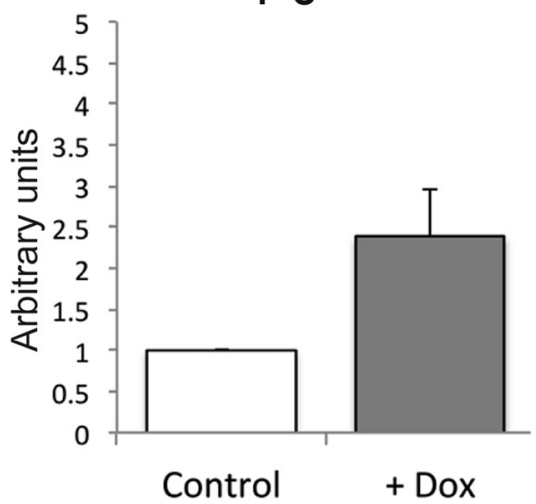

B
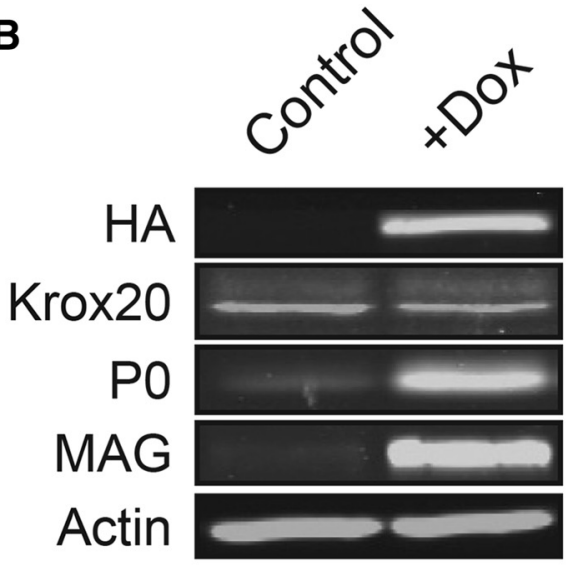

MAG

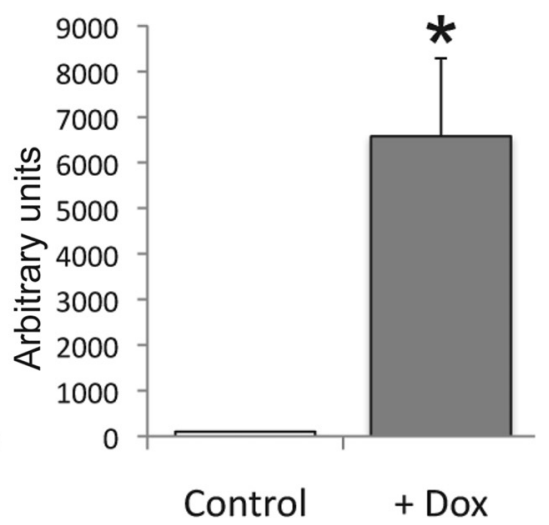

MAG

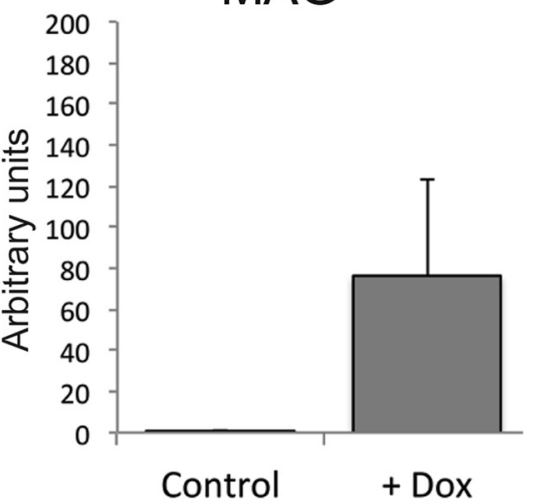

Figure 3. Akt activation promotes myelin formation independently of Krox20 regulation. Purified Schwann cells infected with doxycycline (Dox)-inducible lentiviruses encoding MyrAkt-HA or GFP were cultured in ascorbic acid containing media in the absence of axons. A, GFP induction with Dox did not affect the basal levels of protein for Krox20, P0, and MAG. Basal levels for MAG were not detectable for quantification; $n=3 . \boldsymbol{B}, \mathbf{C}$, Induction of MyrAkt substantially increased P0 protein levels (358.1-, 586.7-, and 1114.5-fold vs 100, average 686.5 $\pm 223.98, p=0.058$ ) and significantly increased MAG levels (3541.7-, 9467.8-, and 6717.2-fold vs 100, average $6575.6 \pm 1712.19, p=0.045)$, as detected by Western blot. Interestingly, a modest but significant reduction of Krox20 was also detected $(83.8 \pm 5.28, p=0.037)$. Western blot quantification data were normalizing by using values from control samples that were arbitrarily set to $100 ; n=3$. Data are mean \pm SEM. $\boldsymbol{D}$, Krox20 mRNA expression remained unchanged $(0.77 \pm 0.19, p=0.27)$ when Akt was induced with doxycycline. mRNA for P0 and MAG was increased when Akt was induced, although due to the variability of induction (P0 1.7-, 3.5-, and 1.9-fold vs 1, average $2.4 \pm 0.57, p=0.07$; and MAG 17.9-, 168.9-, and 42.2-fold vs 1, average 76.3 $\pm 46.81, p=0.18$ ) compared with the noninduced, the increase in these markers did not achieve significance by the $t$ test. Real-time PCR data were normalized by using values from control samples that were arbitrarily set to 1. GAPDH was used as a reference; $n=3$. Data are mean \pm SEM. ${ }^{*} p<0.05$.

of BrdU for 4 h. Cells were then fixed in PFA 4\%, permeabilized with methanol, and treated as previously described (Maurel and Salzer, 2000). The ratio of BrdU-positive/Hoechst-positive cells were calculated from nonoverlapping pictures of the whole coverslip. Four independent sets of experiments were performed $(n=4)$, and from each of them, three independent coverslips were screened.

RNA extraction and quantitative real-time PCR. Total RNA was isolated using a RiboPure Kit (Ambion). cDNA was generated from 250 to 
A

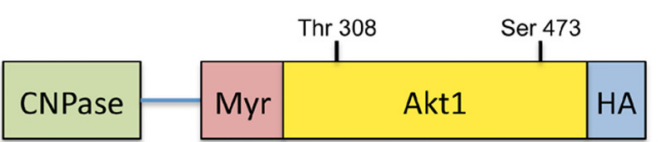

B

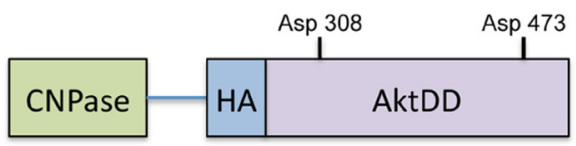

$\mathrm{HA}$

Tub
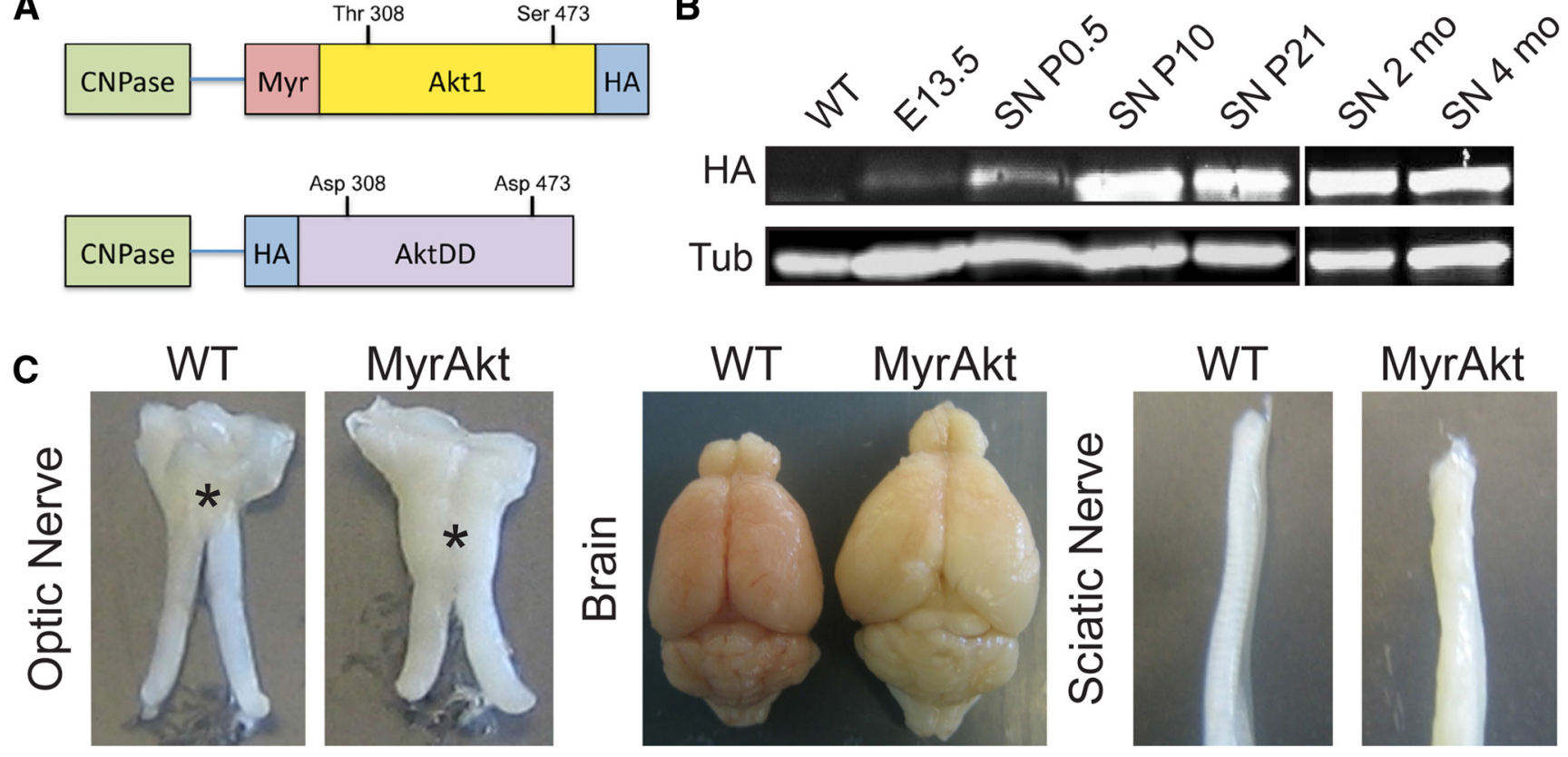

D
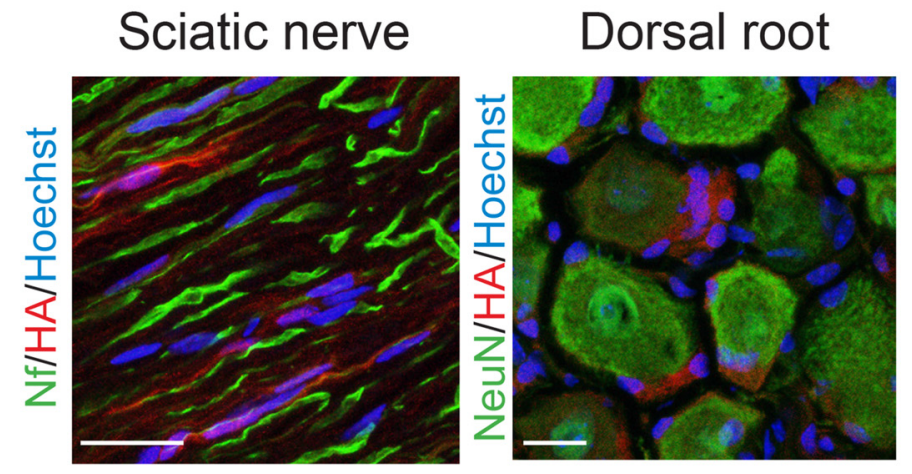

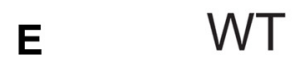

MyrAkt

Figure 4. Constitutively active Akt promotes CNS and PNS hypermyelination. $A$, Scheme illustrating the two constitutively active Akt1 constructs driven by the CNP promoter that were used to establish transgenic mice. $\boldsymbol{B}$, The HA tagged construct was weakly detectable in E13.5 DRGs isolated from transgenic mice and readily detectable in sciatic nerves (SN) from P0.5 until adulthood, with a peak at P10 that correlates with active myelination. C, One-year-old transgenic mice carrying the MyrAkt transgene developed enlarged neural structures. Optic nerves (asterisk indicates the optic chiasm), brains, and sciatic nerves were all enlarged. $\boldsymbol{D}$, In 2-month-old sciatic nerves, HA was present with variable intensity in Schwann cells. HA was detectable in satellite cells from 2-month-old mouse DRGs without any obvious presence in neurons. Scale bars, $20 \mu \mathrm{m}$. E, Four-month-old transgenic brains (MyrAkt) were bigger than WT, with a thicker corpus callosum (blue) and increased MBP staining, evidence of enhanced myelination. Scale bar, $1 \mathrm{~mm}$.

600 ng of total RNA by AMV Reverse Transcriptase (Promega), and the transcripts were detected and amplified by quantitative real-time PCR in a LightCycler machine (Roche) following the manufacturer's instructions. GAPDH was used as internal control. Real-time PCR conditions were as follows: 1 cycle $10 \mathrm{~min} 95^{\circ} \mathrm{C}, 50$ cycles $\left(30 \mathrm{~s} 95^{\circ} \mathrm{C}, 30 \mathrm{~s} 56^{\circ} \mathrm{C}, 30 \mathrm{~s}\right.$ $72^{\circ} \mathrm{C}$ ), 1 cycle $1 \mathrm{~min} 95^{\circ} \mathrm{C}, 30 \mathrm{~s} 55^{\circ} \mathrm{C}$ and $30 \mathrm{~s} 95^{\circ} \mathrm{C}$. Primers were as follows: MAG forward 5' ${ }^{\prime}$ ACC TTG CAG TTC GAG GGT TA-3', MAG reverse 5' -ACA GAG CAG GCT GAC ATG G-3'; $M B P$ forward 5' -ACT ACC CAC TAC GGC TCC CT- $3^{\prime}$, MBP reverse $5^{\prime}$-GGG TGT ACG AGG TGT CAC AA-3'; Krox20 forward $5^{\prime}$-GGT GTG TGT ACC ATG TCC CA-3', Krox20 reverse 5'-CCA GAG AGG AGG TGG AAG TG-3'; GAPDH forward 5'-AGA AGA CTG TGG ATG GCC C-3'; GAPDH reverse $5^{\prime}$-TTC AGC TCT GGG ATG ACC TT-3'; MPZ forward 5' -TCC CTC ATC CAG CCC CAG CC-3', MPZ reverse 5' -CTG GGA GCG CAC AGC ACC AT-3'.

Rapamycin treatment in vivo. The drug was dissolved in vehicle solution containing $5 \%$ polyethylene glycol $400,5 \%$ Tween 80 , and $8 \%$ ethanol. Rapamycin $(7.5 \mathrm{mg} / \mathrm{kg})$ or vehicle was administered intraperitoneally for $5 \mathrm{~d}$ per week during 8 weeks. Mice were treated beginning at 5 weeks of age and were weighed every week to adjust the treatment. A total of 21 mice were treated, $7 \mathrm{WT}$ and $7 \mathrm{Tg}$ with vehicle, and $7 \mathrm{Tg}$ with rapamycin. Two independent rounds of treatment were done for morphometric and Western blot analyses.

Electronic microscopy and morphometric analysis. Control and treated 3 -week-old myelinating cocultures grown on collagen-coated glass coverslips were rinsed in PBS and fixed overnight at $4^{\circ} \mathrm{C}$ in $2 \%$ glutaraldehyde in $0.1 \mathrm{~m}$ phosphate buffer, $\mathrm{pH} 7.0(0.1 \mathrm{M} \mathrm{PB})$. After gently removing the fixed cultures from the coverslips, they were washed in $0.1 \mathrm{M} \mathrm{PB}$, incubated in $2 \%$ osmium tetroxide in $0.1 \mathrm{M} \mathrm{PB}$ for $1 \mathrm{~h}$, and processed for flat embedding in EMbed 812 (Electron Microscopy Sciences). Ultrathin sections were counterstained with uranyl acetate and Reynold's lead citrate and examined on a Philips CM10 electron microscope. For the in vivo analysis, mice were fixed via transcardial perfusion with $4 \%$ PFA, $2.5 \%$ glutaraldehyde, and $0.1 \mathrm{~m}$ sucrose in $0.1 \mathrm{M} \mathrm{PB}, \mathrm{pH}$ 7.4. Sciatic nerves, spinal roots (L4 level), optic nerve, and sympathetic tract were collected. Tissues embedded in EMbed 812 were sectioned on a Leica UCT ultramicrotome at a thickness of $1 \mu \mathrm{m}$ and stained with a solution of $1 \%$ toluidine blue. For TEM, tissues embedded in EMbed 812 were sectioned on a Leica UC6 ultramicrotome at a thickness of $90 \mathrm{~nm}$ and placed on copper slotted grids or occasionally on mesh grids. Sections 
A
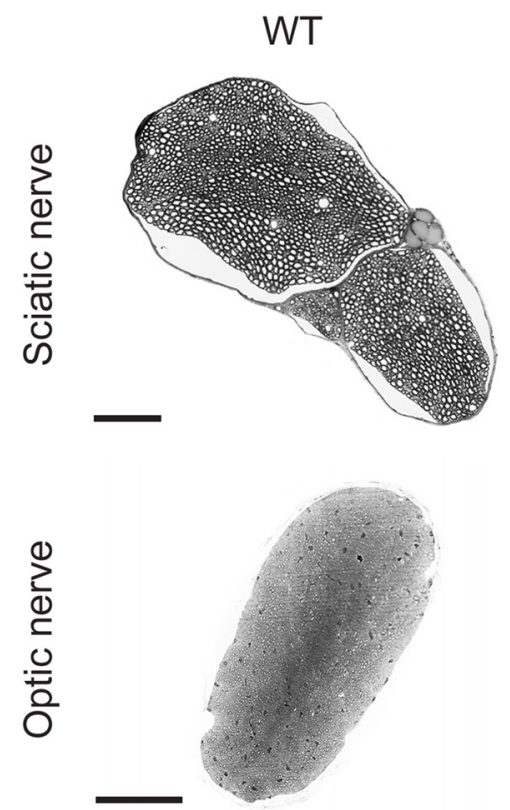

MyrAkt
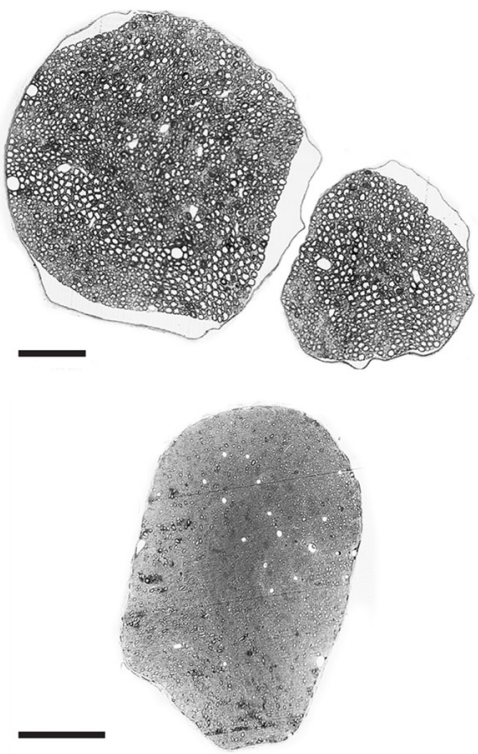

B

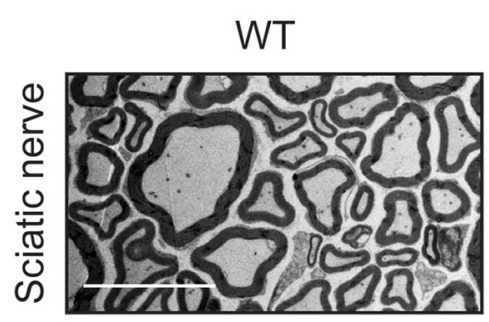

MyrAkt

AktDD
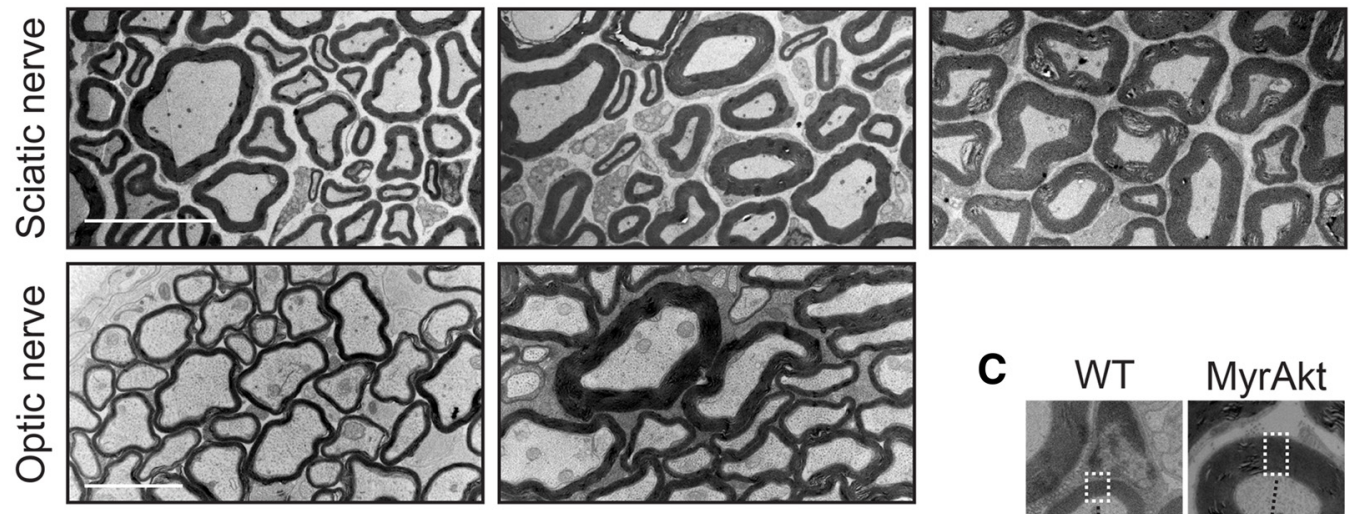

D

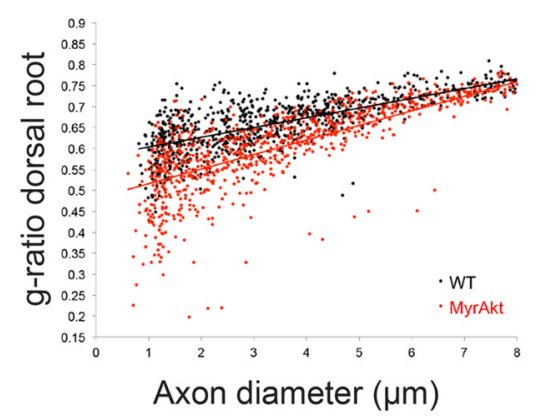

E

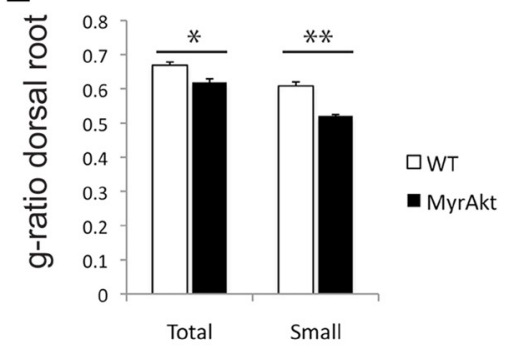

\section{F}

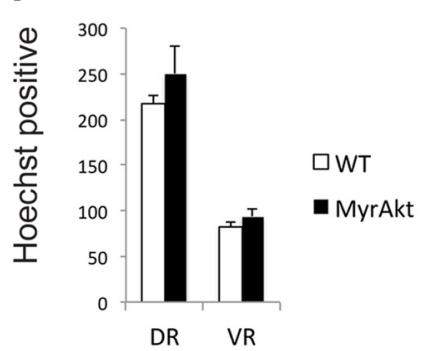

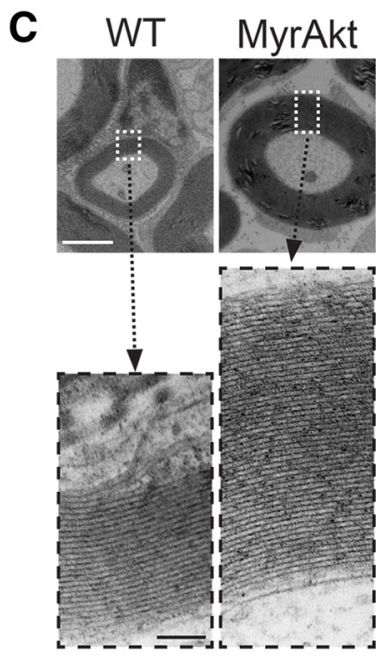

Figure 5. Nerves from transgenic mice are hypermyelinated. A, At 5 months, sciatic and optic nerves from MyrAkt transgenics were enlarged compared with WT mice, as seen in transverse, toluidine blue-stained sections. Scale bar, $100 \mu \mathrm{m}$. B, EM sections show thicker myelin sheaths in 5-month-old MyrAkt and AktDD sciatic nerves. Optic nerves from MyrAkt were also hypermyelinated. Scale bars: sciatic nerve, $10 \mu \mathrm{m}$; optic nerve, $2 \mu \mathrm{m}$. C, The myelin sheaths in transgenic nerves had increased numbers of myelin lamellae (Figure legend continues.) 
were stained with $3 \%$ uranyl acetate in $50 \%$ methanol for 20 min followed by lead citrate for $5 \mathrm{~min}$. Grids were viewed on a Philips CM12 Tungsten Emission TEM at $120 \mathrm{kV}$ and imaged with a GATAN $4 \mathrm{k} \times 2.7 \mathrm{k}$ digital camera.

For g-ratios, nonoverlapping digitized images of fiber cross-sections from dorsal roots were obtained and analyzed using Nikon software. g-ratios were calculated by dividing the axon diameter by the total fiber diameter. g-ratios were determined exclusively in the dorsal root due to their mix of small- and large-caliber axons. All fibers with myelin abnormalities or fixation artifacts were excluded from analysis. Three animals per genotype were used for the WT/MyrAkt data (see Fig. $5 D, E$ ), and four animals per genotype and conditions were quantified for the rapamycin experiments (see Fig. 9D). The number of axons per Remak bundle and the number of axons in Schwann cell pockets were counted in the sciatic nerve by using ImageJ software (National Institutes of Health). The number of axons per $100 \mu \mathrm{m}^{2}$ and the total number of myelin abnormalities per sciatic nerve were determined from merged micrographs of thin sciatic nerve sections $(400 \times)$, assembled with Adobe Photoshop (see Fig. 9C). Overlapping digitized images (400×) from thin sections of dorsal and ventral roots were merged to determine the total number of myelinated axons in Figure $6 F$.

Statistical analysis. The unpaired two-tailed $t$ test was performed on all data to assess significance. In each case, the SEM is shown in the plots, although only the upper part of the SEM is depicted. Each $n$ represents a different independent experiment or animal.

\section{Results}

\section{Akt activity is required for myelination and axon sorting}

To address a role of Akt in myelination, we first examined Aktnull mice for any abnormalities in the peripheral nerves. There are three Akt genes (Akt1, Akt2, and Akt3), each with different tissue expressions and substrate affinities (Easton et al., 2005; Tschopp et al., 2005; Franke, 2008; Leavens et al., 2009). Western blot analysis revealed that Akt1 is expressed in both neurons and Schwann cells, whereas Akt 2 and Akt 3 are primarily expressed by Schwann cells and neurons, respectively (Fig. 1A). We next examined whether mice deficient in each of these Akt isoforms exhibit myelination defects by comparing sciatic nerves from 2-month-old WT versus knock-out mice via semithin sections. There were no obvious differences between the knock-out mice and their WT littermates in terms of nerve size or the extent of myelination (Fig. 1B). No obvious abnormalities of myelinated fibers or Remak bundles were evident on inspection of electron micrographs of the Akt mutants versus their WT littermates (Fig. $1 B a-B f)$. The overall preservation of morphology in individual mutants likely reflects compensation by remaining Akt isoforms.

We therefore undertook to inhibit all Akt activity with the pharmacological inhibitor perifosine (Pf), an alkylphospholipid that impairs Akt by blocking its PH domain (Hennessy et al., 2007; Gills and Dennis, 2009). In parallel, we inhibited PI3K activity with the LY294002 (LY) inhibitor (Vlahos et al., 1994; Maurel and Salzer, 2000). Treatment of cocultures with each inhibitor blocked nearly all myelin formation (Fig. $2 A, B$ ). In agree-

\footnotetext{
$\leftarrow$

(Figure legend continued.) (scale bar, $1 \mu \mathrm{m}$ ) and revealed no change in the periodicity of the myelin lamellae (scale bar, $100 \mathrm{~nm}$ ). $\boldsymbol{D}$, g-ratio analysis revealed that hypermyelination was more pronounced in small-caliber axons $(0.5-2 \mu \mathrm{m}) . \boldsymbol{E}$, Average g-ratio in the transgenic dorsal root was lower than in WT $(0.62 \pm 0.01$ vs $0.67 \pm 0.01$, respectively, $p=0.02)$. A total of $250-300$ axons between 0.5 and $8 \mu \mathrm{m}$ were measured. This difference was accentuated when only small-caliber axons $(0.5-2 \mu \mathrm{m})$ were considered $(0.52 \pm 0.004$ vs $0.61 \pm 0.01$, $p=0.002) ; n=3$. Data are mean \pm SEM. $\boldsymbol{F}$, The numbers of Schwann cell nuclei were comparable in WT and MyrAkt dorsal roots (DR) (216 \pm 9.7 vs $250 \pm 29.2$, respectively) and ventral roots (VR) ( $82 \pm 5.5$ vs $94 \pm 8.1$, respectively) from 5 -month-old animals; $n=4$. Data are mean \pm SEM. ${ }^{*} p<0.05 .{ }^{* *} p<0.01$.
}

ment, expression levels of $\mathrm{MBP}$ and $\mathrm{P} 0$ protein (Fig. 2C,D) were significantly reduced in the Pf-treated and nearly absent in the LY-treated cocultures. mRNA levels for MBP were dramatically reduced in the presence of either drug, whereas the effect of Pf on P0 was more modest, perhaps due to its higher basal levels of expression (Fig. 2E). Unexpectedly, Oct6/POU3F1 and Krox20, key transcription factors for PNS myelination, were robustly expressed in the nuclei of the Pf-treated Schwann cells (Fig. 2A), and the levels of Krox20 protein (Fig. 2C,D) and mRNA (Fig. 2E) were unaffected. These results suggest that the promyelinating effects of Akt are independent of Krox20. In contrast to Pf, cocultures treated with LY did not express any Krox20 protein or mRNA (Fig. 2A, C-E).

There was no effect of Pf on Schwann cell proliferation in the cocultures (Fig. $2 F$ ), in further contrast to LY (Fig. $2 F$ ), which is known to inhibit Schwann cell proliferation induced by axonal neuregulin (Maurel and Salzer, 2000). Consequently, Schwann cell numbers were markedly reduced in the LY-treated, but not the Pf-treated, cocultures (Fig. 2A). To determine whether reduced numbers of Schwann cells in the LY-treated cocultures contributed to the limited expression of Krox20, we seeded a fivefold excess of SCs before treatment with LY. No significant Krox20 or myelin protein expression was detected under these conditions (data not shown), indicating that the effects of LY are independent of an effect on cell numbers.

Our results confirm that PI $3 \mathrm{~K}$ activity is crucial for myelination in vitro and reveal that its effector Akt controls myelin mRNA and protein expression in the PNS, independent of Krox20 regulation. The data also suggest that PI3K regulates Schwann cell proliferation and the expression of myelin transcription factors by mechanisms independent of Akt.

Ultrastructural analysis of these cultures further revealed that Pf and LY differentially affected Schwann cell ensheathment. Schwann cells in the Pf-treated cultures partially surrounded the axons, although they did not completely wrap most of them (Fig. $2 G$ ). In contrast, in the LY-treated cocultures, Schwann cells were apposed to but completely failed to ensheathe axons (Fig. 2G). Myelination was dramatically reduced by both treatments.

\section{Activated Akt enhances myelin protein and mRNA expression in vitro independent of Krox20 levels}

We next examined whether Akt activity is not only necessary but is also sufficient for triggering myelination. We used a lentiviral vector to express a doxycycline-inducible, HA-tagged myristoylated Akt (MyrAkt) in cultured Schwann cells. MyrAkt is expressed and active at the membrane independent of PIP3 concentrations. After infection, Schwann cell cultures were maintained on media containing ascorbate in the presence or absence of doxycycline for $4 \mathrm{~d}$. Schwann cells infected with a doxycycline-inducible lentivirus encoding GFP, which served as a control, displayed no increase of myelin proteins or Krox20 (Fig. 3A). In general, the expression of activated Akt increased MAG and P0 protein and mRNA levels; this increase was significant in the case of MAG protein (Fig. $3 B-D$ ). Interestingly, Krox 20 protein levels were slightly reduced, and mRNA levels unchanged despite the induction of myelin proteins following MyrAkt expression (Fig. 3B-D), suggesting that these changes were independent of Krox20 regulation.

\section{Transgenic expression of activated Akt isoforms results in PNS hypermyelination}

To assess the role of Akt in vivo, we generated transgenic mice expressing HA-tagged MyrAkt or AktDD in myelinating glia un- 
A

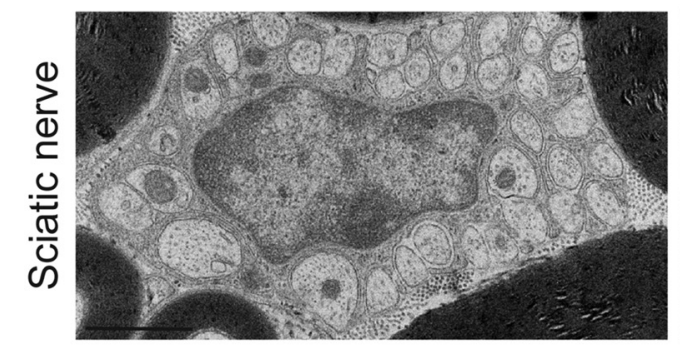

WT

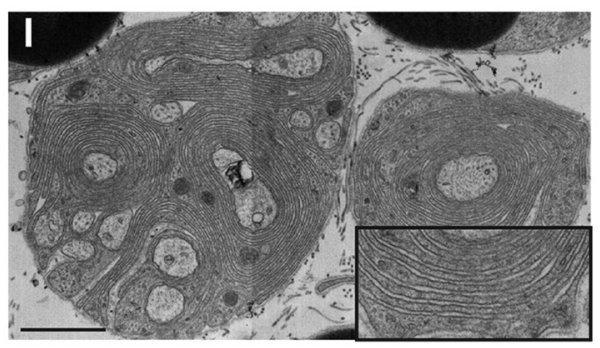

MyrAkt

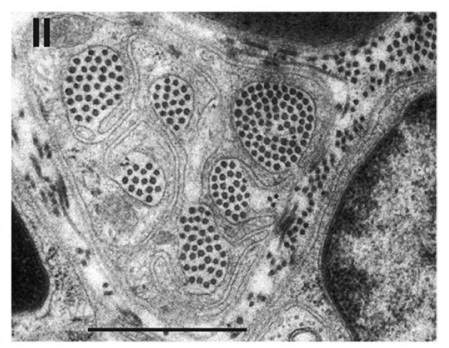

B

MyrAkt
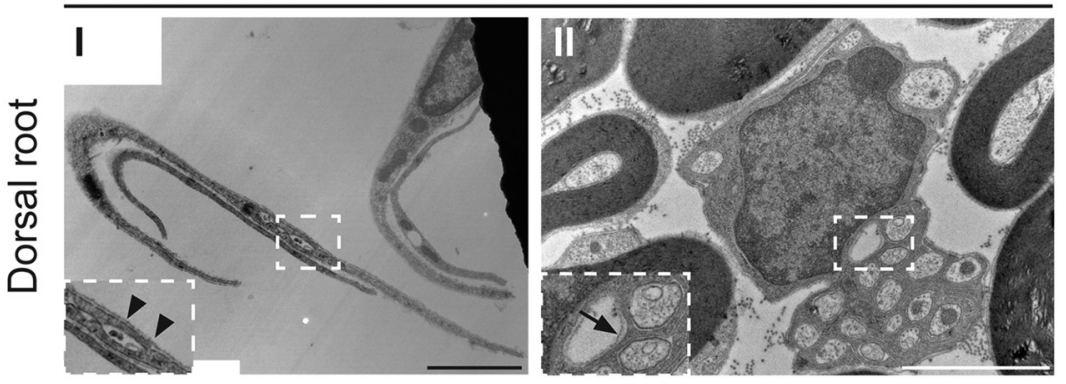

C

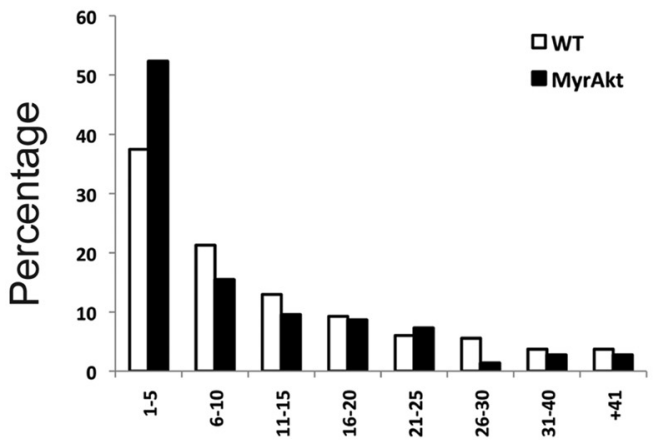

D

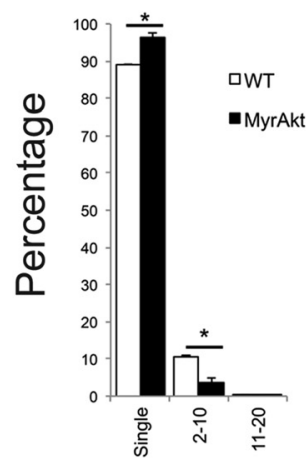

\section{Axons / Remak bundle}

Axons / SC pocket
E

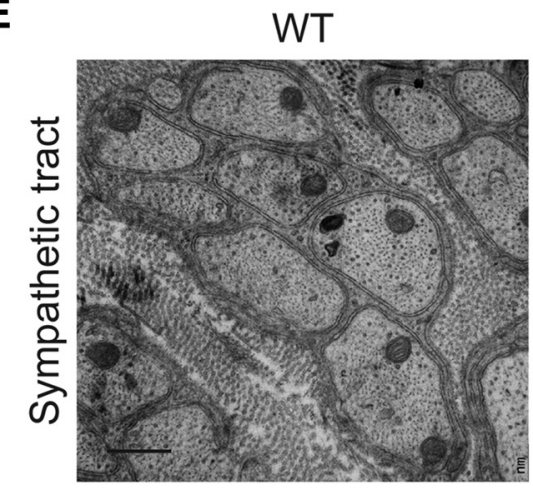

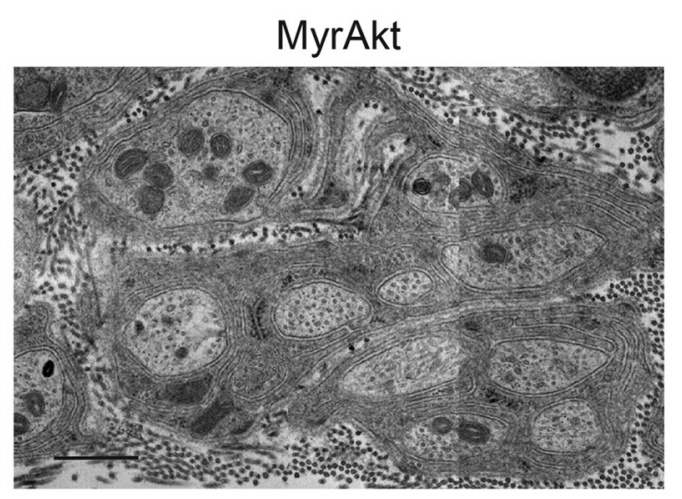

$\mathbf{F}$

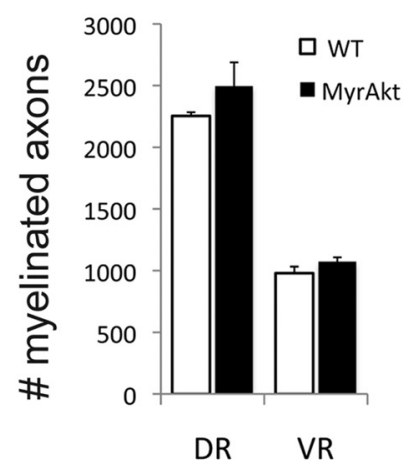

Figure 6. Activated Akt enhances wrapping and sorting but not myelination of axons in Remak Schwann cells. A, EM micrographs from 20-month-old mice reveal aberrant axon-Schwann cell relationships in Remak bundles in transgenic compared with WT mice. Small axons were often surrounded by circumferential layers of uncompacted Schwann cell membranes (AI, shown at higher magnification in inset). Schwann cell membranes surrounding collagen fibers (AII) were also present in the transgenic nerves and were frequently covered by basal lamina. Scale bar, $1 \mu \mathrm{m}$. $\boldsymbol{B}$, In 5-month-old-mice, Schwann cell processes (BI), with associated basal lamina without apparent axonal contact, are present. Arrowheads indicate basal lamina deposition. Schwann cells also formed empty pockets with basal lamina deposited in the interior (BII, inset, arrow). Scale bars, $2 \mu \mathrm{m}$. $\boldsymbol{C}$, Bar graph showing the distribution of the numbers of axons per Schwann cell; Remak bundles with only a few axons (1-5) are increased in the 5-month-old transgenic mice. $D$, The number of axons per pocket was also decreased in the 5 -month-old Tg, suggesting better segregation of axons (one axon per pocket WT $89.12 \pm 0.007$ vs $\operatorname{Tg} 96.12 \pm 1.17, p=0.027 ; 2-10$ axons WT $10.59 \pm 0.28$ vs Tg $3.83 \pm 1.22, p=0.03 ; 11-20$ axons WT $0.28 \pm 0.28$ vs Tg $0.04 \pm 0.04$, not significant); $n=2$. A total of 100 bundles from sciatic nerves were analyzed per animal. $E$, Electron micrographs of the sympathetic tract from 20-month-old mice are shown. No myelinated fibers are present, but multilammelar wrapping of axons and collagen fibrils is seen, consistent with a role of Akt in wrapping. Scale bar, $500 \mathrm{~nm}$. $\boldsymbol{F}$, The numbers of myelinated axons in transgenic dorsal (DR) and ventral (VR) roots at 5 months were not statistically different in MyrAkt versus WT mice; $n=2 . D, F$, Data are mean \pm SEM. ${ }^{*} p<0.05$. 
A

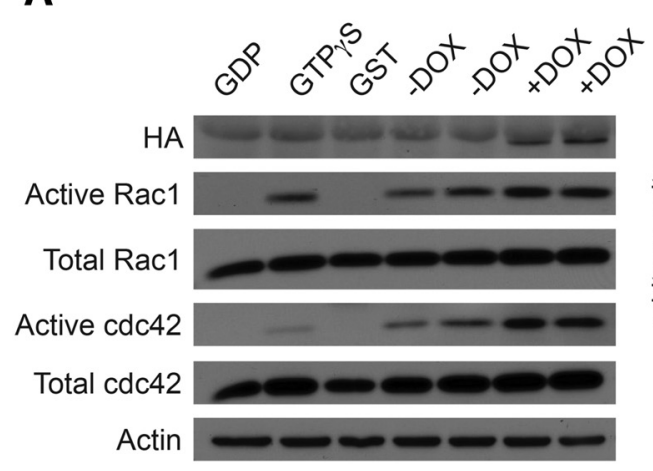

B

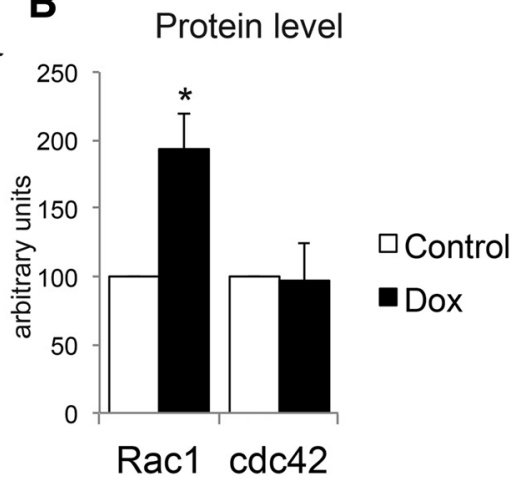

Figure 7. MyrAkt induces Rac1 activity in cultured Schwann cells. A, Western blot showing the controls (GDP, GTP $\gamma$ S, and GST) as well as samples from noninduced ( - DOX) and doxycycline-induced ( + DOX) Schwann cell pools transfected with the MyrAkt construct. The same -DOX and +DOX samples were loaded into two consecutive lines. B, Quantification of Rac1 and cdc 42 levels. Values shown represent active GTPase levels divided by total GTPase levels and corrected for actin, which served as a loading control. All data were normalized to noninduced controls, which were set to 100 . Induction of MyrAkt by addition of doxycycline to the culture media increased Rac1 activity significantly $(193 \pm 25.31, p=0.01)$ but not cdc42 (96.82 $\pm 27.11, p=0.91)$. After correction for total cdc 42 and loading amounts, the level of active cdc 42 in $A$ is not significantly increased. Data are mean $\pm S E M$. Rac1, $n=4$ independent sets of experiments; cdc42: $n=3$ independent sets of experiments. ${ }^{*} p<0.05$.

der control of CNP promoter elements (Fig. 4A). Both Akt1 isoforms are constitutively active as the result of either being targeting to the membrane (MyrAkt) or via mutations of two phosphorylation sites (Thr308 and Ser473) to aspartate that mimic the activated state (AktDD) (Fig. 4A). We generated four CNP-MyrAkt-positive founders and three transgenic CNPAktDD founders. All four CNP-MyrAkt lines exhibited enlarged brains and optic and sciatic nerves; this was evident at several months of age and quite pronounced at 1 year of age (Fig. 4C). Because of breeding problems with the CNP-AktDD mice, only founders were analyzed. Only one of the CNP-AktDD founder mice exhibited a hypermyelinated phenotype, evident in the sciatic nerves (Fig. 5B).

Two of the CNP-MyrAkt that transmitted the transgene were analyzed in detail. In each case, transgenic mice were phenotypically indistinguishable from WT littermates until $\sim 1$ year of age when they developed limited motility and breathing difficulties. In agreement with the expression of CNP (Chandross et al., 1999), the HA tagged transgene was detected in transgenic sciatic nerves at P0.5, the earliest time point examined (Fig. 4B). Its expression increased during active myelination (P10-P21) and remained robust into adulthood. Expression of the HA tag was also detectable in DRGs directly isolated from E13.5 embryos (Fig. 4B), likely reflecting the presence of glial/satellite cells in these DRGs. In agreement, staining of adult DRGs and sciatic nerves was largely, if not exclusively, confined to glial cells (Fig. 4D).

Transgenic mice were hypermyelinated in both the CNS and PNS. CNS hypermyelination was evident by increased MBP staining on coronal sections and an increase in the size of the corpus callosum (Fig. 4E). Both the sciatic and optic nerves were also markedly expanded in diameter, based on toluidine blue staining of semithin sections (Fig. 5A). Electron micrographs showed that individual nerve fibers were hypermyelinated (Fig. $5 B$ ), evident as an increase in the number of myelin lamellae; myelin periodicity was unaffected (Fig. 5C). g-ratios were significantly decreased in 5-month-old transgenic mice (Figs. 5D,E). Hypermyelination was most pronounced in small-caliber axons: that is, those $<2 \mu \mathrm{m}$ in diameter in both the dorsal roots (Fig. $5 D, E)$ and ventral roots (data not shown).
The total numbers of Hoechst-positive cells in the ventral and dorsal roots were counted. No significant differences in cell numbers were detected in four transgenic roots compared with roots from their WT littermates (Fig. 5F). These results suggest that, in our system, tissue hypertrophy results from an Akt-mediated increase in myelin and, perhaps, increased extracellular matrix production, rather than increased numbers of cells.

\section{Akt activation promotes Schwann cell wrapping but does not alter the ensheathment fate of axons}

Remak fibers were also affected in the CNP-MyrAkt transgenic mice. In WT nerves as expected, small-caliber axons were enclosed within individual pockets of a single unmyelinated Schwann cell (Fig. 6A). In contrast, in the transgenic nerves, multiple layers of Schwann cell membrane frequently wrapped smallcaliber axons. High-power micrographs revealed that these wrapped membranes were noncompacted (Fig. 6A, inset, middle); pockets with a normal structure that enclosed axons were absent (Fig. 6AI). Transgenic Schwann cell pockets sometimes contained collagen fibers rather than axons; these were more frequent in older animals and were surrounded by basal lamina (Fig. 6AII). Indeed, Schwann cell processes were also seen surrounded by basal lamina without any axonal contact, suggesting that Akt can drive Schwann cell basal lamina formation in the absence of axonal signals (Fig. 6BI). Some pockets were formed even without any detectable content (Fig. 6BII); and, in such cases, a reversed orientation of the basal lamina was detected, secreted inside the empty pocket (Fig. 6BII). Finally, there was a trend to enhanced segregation of unmyelinated axons. This was evidenced by an increase in transgenic Remak bundles that enclosed just one to five axons (quantified in Fig. 6C) or with singleaxon pockets (Fig. 6D) compared with WT bundles.

We also asked whether Akt activation is sufficient to convert unmyelinated, postganglionic sympathetic nerve fibers to a myelinated fate, akin to the effects of overexpressing Nrg1III in these axons (Taveggia et al., 2005). Examination of the sympathetic tract of transgenic mice (Fig. $6 E$ ) revealed that fibers were consistently unmyelinated. Instead, multiple layers of Schwann cell membrane surrounded the axons, thus resembling the Remak bundles in the sciatic nerves and dorsal roots of the transgenic mice. Schwann cell pockets containing only extracellular matrix were also found in this tract (Fig. 6E).

In agreement with a lack of effect on myelination, the proportion of myelinated fibers in the dorsal and ventral roots of transgenic and WT mice were comparable (Fig. $6 F$ ). Together, these data suggest that Akt regulates axonal wrapping and that other signals are required for myelination.

\section{MyrAkt specifically enhances Rac1 activity in Schwann cells} Racl and cdc42 are crucial for proper sorting of axons at early stages of myelination; their precise roles differ as cdc42 controls the pool of Schwann cells by affecting proliferation, whereas Rac1 induces radial lamellopodia required to sort axons (Benninger et al., 2007; Nodari et al., 2007). To assess whether the enhanced axonal sorting and wrapping observed in MyrAkt animals might 
A
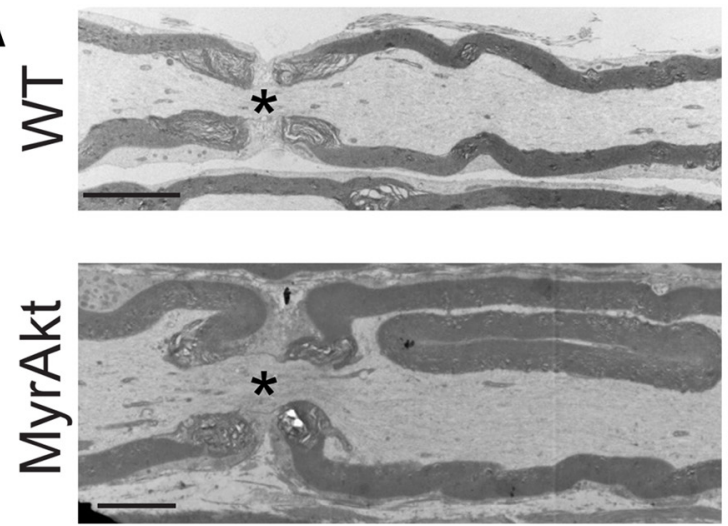

B
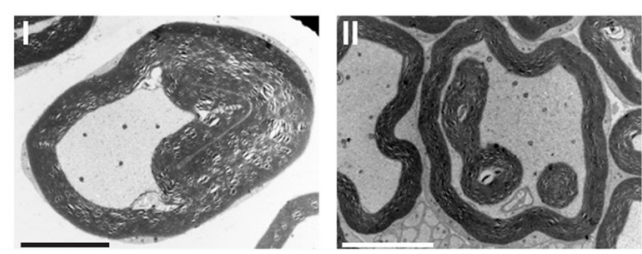

D

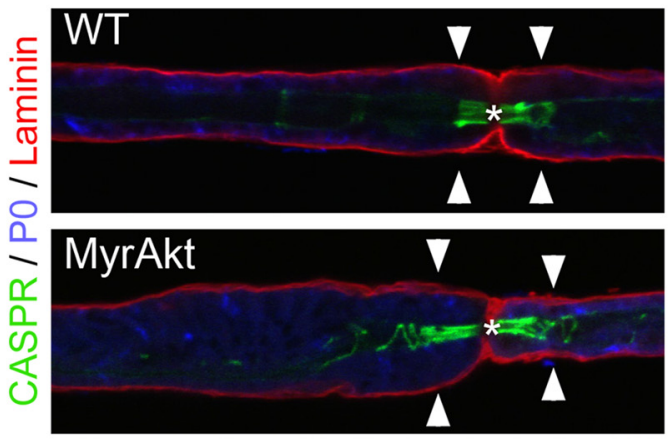

E

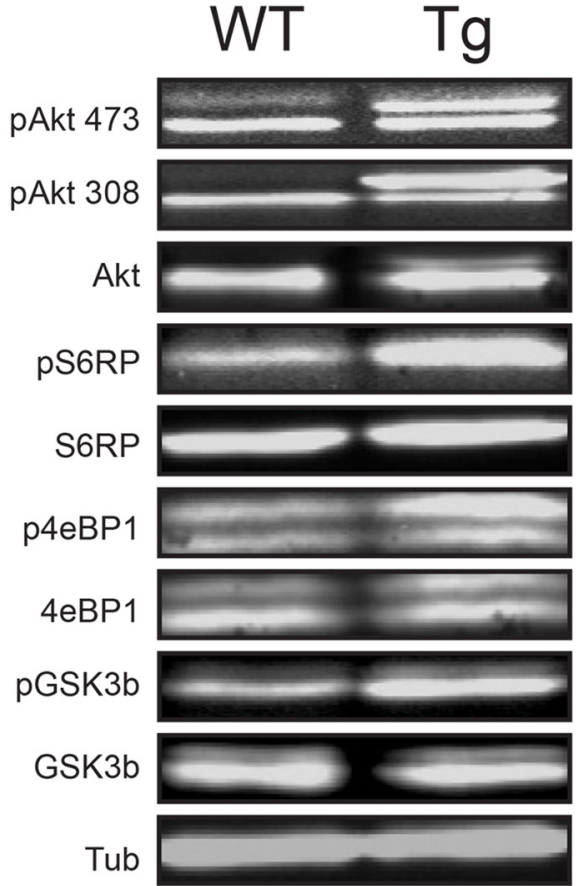

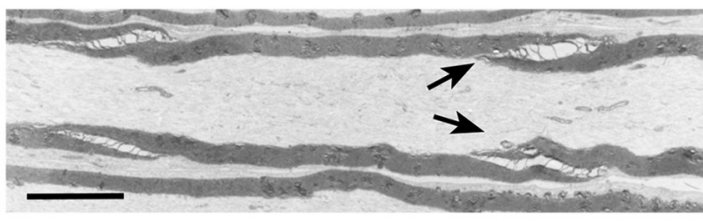
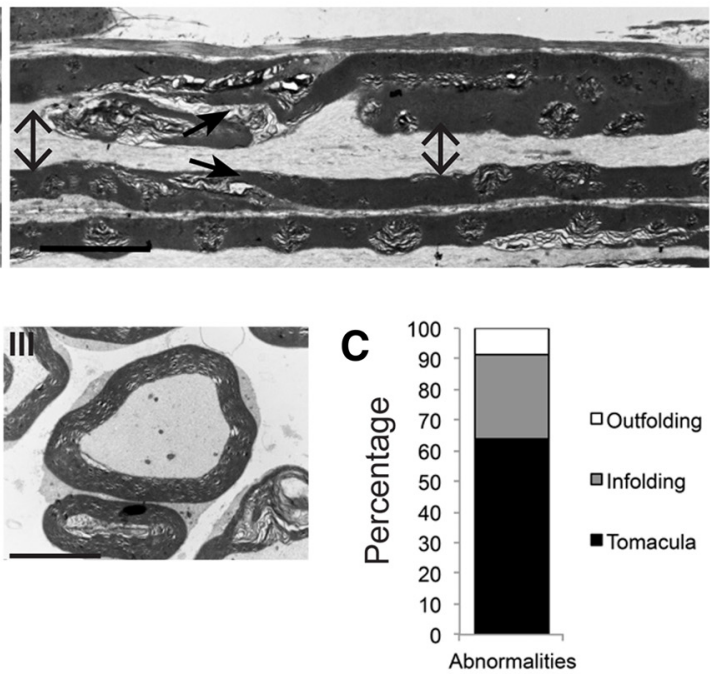

$\mathbf{F}$
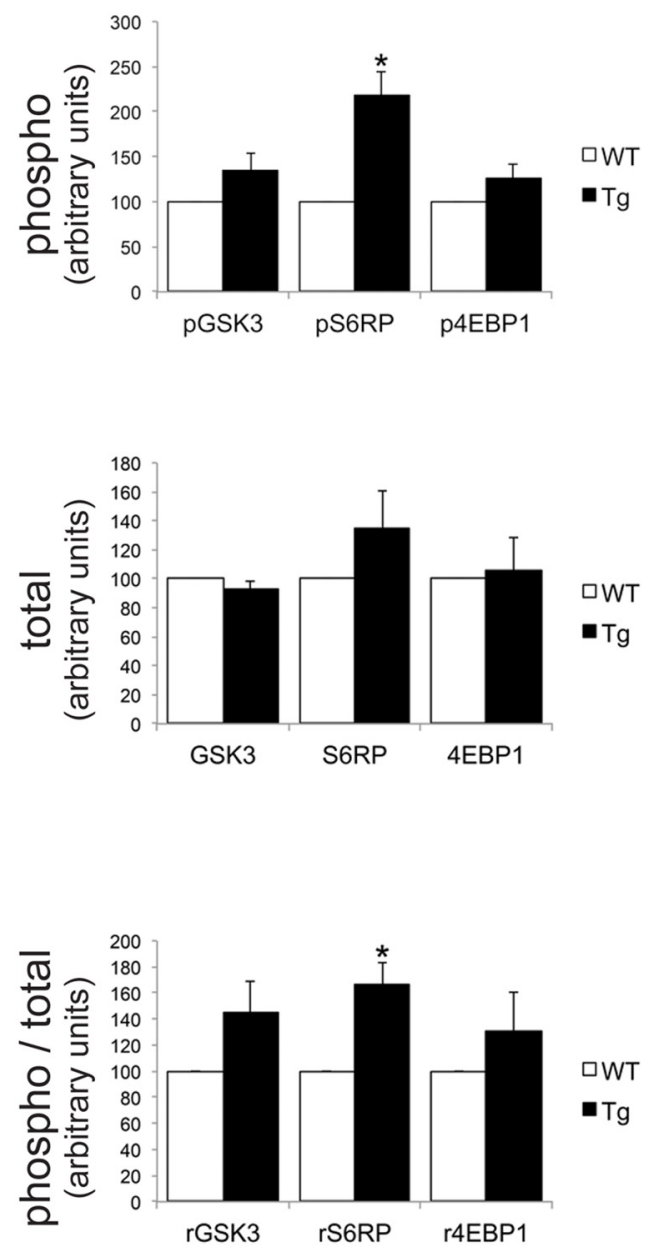

Figure 8. Sciatic nerves of MyrAkt transgenic mice exhibit tomacular defects and activation of mTOR. A, Top, Longitudinal electron micrographs of sciatic nerves from 5-month-old WT animals. Asterisk indicates nodes. Arrows indicate clefts. Bottom, Longitudinal electron micrographs of sciatic nerves from transgenic animals reveal myelin infolding at the paranodes (left panel) and tomacula near the clefts (indicated with arrows), resulting in compression of the axon (right panel). Scale bars, $5 \mu \mathrm{m}$. B, Example of the different myelin (Figure legend continues.) 
reflect activation of Racl or cdc42, we induced MyrAkt in cultured Schwann cells. Induction of Akt led to activation of Rac1, but not cdc42, based on pull-downs with GST-Pak1 (Fig. 7 A, B); there was no change in total levels of either Racl or cdc42. These data suggest that part of the phenotype observed in the transgenic mice, such as enhanced Schwann cell sorting, is a consequence of increased Racl activity.

\section{Transgenic nerves develop tomacula and myelin outfoldings/infoldings}

A consistent finding in the MyrAkt sciatic nerves was the presence of numerous myelin abnormalities. These included myelin outfoldings, a histological hallmark of some Charcot-Marie-Tooth (CMT) forms, notably CMT4B (Bolis et al., 2005; Tersar et al., 2007) and tomacula (i.e., focal thickenings of the myelin sheath characteristic of hereditary neuropathy with liability to pressure palsies) (Adlkofer et al., 1997); tomacula were also seen in the PTEN conditional knock-out mice (Goebbels et al., 2012). Fivemonth-old nerves developed mostly myelin infoldings (Fig. $8 \mathrm{~A}$, left, $B I I$ ) and tomacula (Fig. $8 A$, right, $B I$ ). These changes were preferentially located to regions of noncompacted myelin (i.e., the paranodes and Schmidt-Lanterman incisures). Tomacula were accompanied by axonal compression at the affected regions, although no axonal degeneration was detected at the ages examined (up to 1 year old). Other abnormalities, such as myelin outfoldings, were observed in a lower proportion of cases (Fig. $8 B I I I, C)$. Teased fibers from transgenic sciatic nerves also revealed presumptive tomacula, which were either symmetric (both sides of the affected node) or asymmetric (only one side affected, e.g., Fig. 8D). Similar asymmetry of hypermyelination was also observed (data not shown).

\section{Rapamycin treatment prevents myelin abnormalities in vivo} The mTOR pathway has been previously implicated in the Aktmediated hypermyelination in the CNS (Flores et al., 2008; Narayanan et al., 2009; Goebbels et al., 2010) and PNS (Goebbels et al., 2012; Sherman et al., 2012; Norrmén et al., 2014). In agreement, MyrAkt activates mTOR in the PNS based on Western blot analysis of sciatic nerve lysates. Increased phosphorylation of Akt at both the $\mathrm{S} 473$ or Th308 residues was readily detected in the transgenics by the appearance of an extra phosphorylated Akt band resulting from the myristoylation tag (Fig. 8E). A statistically significant increase of phospho-S6RP (S235/236) levels, an indirect substrate of $\mathrm{mTORC} 1$ and readout of Akt activation, was found in samples from transgenic animals compared with their WT littermates (Fig. 8E,F). The levels of phospho-GSK3b (S9) and the translation repressor protein phospho-4E-BP1 (Thr37/ 46) were also increased in those nerves, although they did not reach statistical significance. No significant differences were

$\leftarrow$

(Figure legend continued.) abnormalities observed in sciatic nerves: I, tomacula, showing compression of the axon; II, infolding; and III, outfolding. Scale bars, $5 \mu \mathrm{m}$. C, Percentages for each of the major myelin abnormalities found in cross-sections from 3-month-old transgenic sciatic nerves; $n=3$. D, Teased fiber from 6-month-old transgenic mouse shows an example of an asymmetric tomacular defect with enlargement in the paranodal region of the left myelin sheath but not the right myelin sheath. Asterisk indicates node. $\boldsymbol{E}$, Western blot analysis of extracts from nerves from 2-month-old WT and transgenic mice show activation of the MTOR pathway. $\boldsymbol{F}$, Quantification of Western blots demonstrates that phosphorylated S6RP (pS6RP) is increased in Tg nerves $(218.4 \pm 25.79, p=0.01)$, and the ratio of phosphorylated to total S6RP (rS6RP) is also increased $(167.1 \pm 16.04, p=0.014)$; data were normalized to WT values arbitrarily set to 100. Increased phosphorylation of GSK3b and 4EBP1 was also evident but did not reach statistical significance; $n=3$. Data are mean \pm SEM. ${ }^{*} p<0.05$. found for the total levels of any of these proteins (Fig. $8 F$ ). These results confirm that the CNP-MyrAktHA transgene is not only properly expressed but also active in those animals.

Treatment with rapamycin for 8 weeks resulted in a dramatic reduction in sciatic nerve size in MyrAkt mice (Fig. 9A, C) and a correction of hypermyelination (Fig. 9A). The efficacy of the rapamycin treatment on $\mathrm{mTOR}$ activity was corroborated by Western blot analysis (Fig. 9B). Other parameters affected in the MyrAkt transgenics, such as brain size or the number of myelin abnormalities, were also ameliorated by rapamycin treatment and corrected to near WT levels (Fig. 9C). In dorsal roots, g-ratio values were significantly increased in drug-treated versus vehicletreated transgenics $(0.59 \pm 0.02$ and $0.54 \pm 0.01$, respectively $)$, although the values were still somewhat lower than their WT littermates $(0.62 \pm 0.006$; Fig. $9 D)$. Interestingly, no improvement of the hyperwrapping phenotype was detected in the Remak bundles of the rapamycin-treated transgenics (Fig. 9E). Together, our data indicate that mTOR activation has a key role in many but not all of the PNS phenotypes driven by activation of Akt.

\section{Discussion}

PNS myelination is controlled by levels of axonal NRG1III (Michailov et al., 2004; Taveggia et al., 2005), which activates Schwann cell ErbB receptors and thereby PI3K, MAPK, and PLC- $\gamma$; each of these pathways has been implicated in myelination (Pereira et al., 2010, 2012; Salzer, 2015). In the case of PI3K, pharmacological inhibition blocks myelination in vitro at an early stage (Maurel and Salzer, 2000), whereas PI3K gain of function, via conditional ablation of PTEN, results in hypermyelination in vivo with the occasional small-caliber axon switching to a myelinated fate (Goebbels et al., 2010). The serine/threonine kinase Akt is a major effector of PI3K and is thus a candidate to mediate these effects in the PNS. However, a prior study of a transgenic mouse overexpressing Akt-DD in both oligodendrocytes and Schwann cells under the control of the glial promoter PLP demonstrated hypermyelination in the CNS, but not the PNS (Flores et al., 2008). This latter result raised the question of whether the effects of PI3K in the PNS are primarily mediated by Akt or result from Akt-independent signaling by PI3K (Ebi et al., 2013).

We now demonstrate that Akt is indeed a key regulator of PNS myelination based on both loss (perifosine treatment) and gainof-function (transgene) analyses. The expression of a constitutively active Akt under control of the CNP promoter provides some striking similarities and interesting differences with previously reported animal models. In particular, our findings phenocopy important aspects of the PTEN conditional mice (Goebbels et al., 2010, 2012) while differing from the prior Akt transgenic mouse model (Flores et al., 2008). CNP comprises a higher percentage of the total myelin protein in the PNS than does PLP (Patzig et al., 2011), indicating that the lack of a PNS effect in the previously reported PLP-AktDD transgenic mice (Flores et al., 2008) may be due to lower expression levels. In addition, we observed a more consistent hypermyelinating phenotype in the MyrAkt than in the Akt-DD transgenics, each under the control of the CNP promoter, suggesting that the membrane-targeted form of Akt is more potent in promoting hypermyelination.

The promyelinating effect of Akt shown here is consistent with evidence that axonal NRG1III is the main driver of Akt activation (Taveggia et al., 2005; Heller et al., 2014). Indeed, overexpression of NRG1III also results in hypermyelination (Michailov et al., 2004), and our results suggest Akt activation likely strongly contributes to this phenotype. Myelin outfoldings/infoldings are also present in human mutations of MTMR13 in 
A

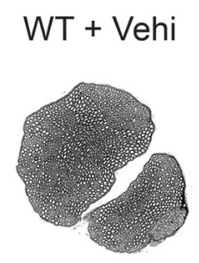

MyrAkt + Vehi
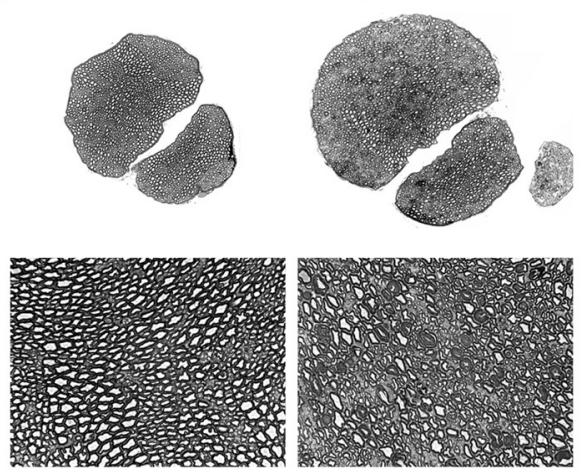

B

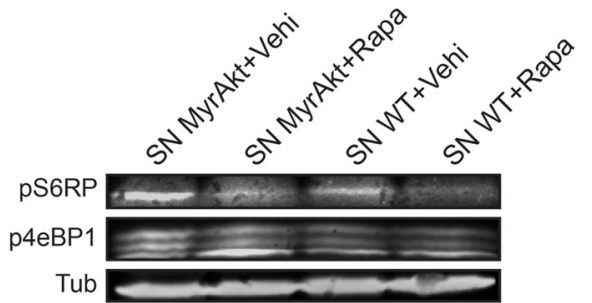

C
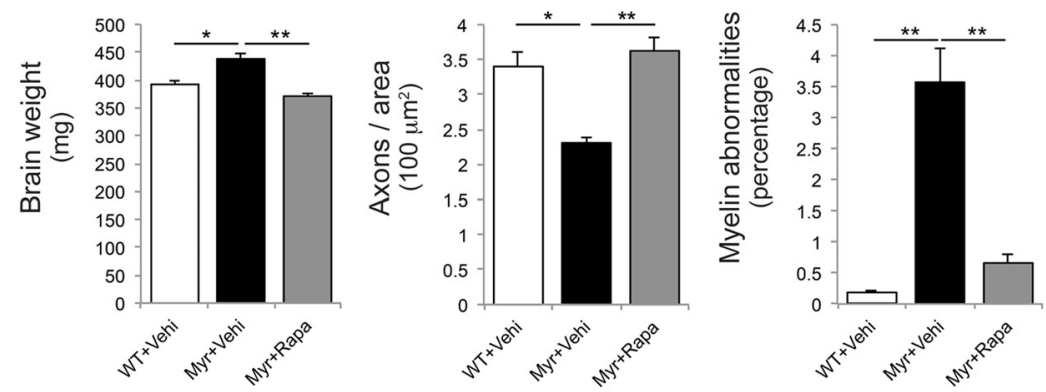

D

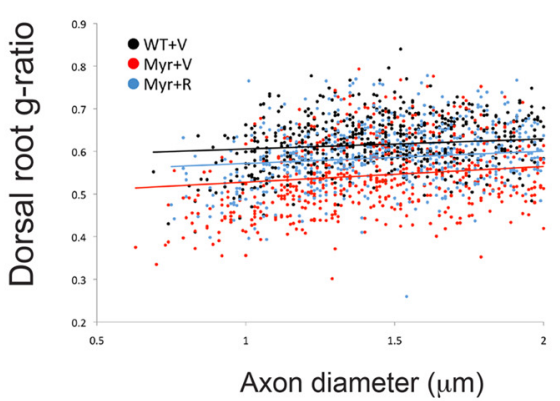

E

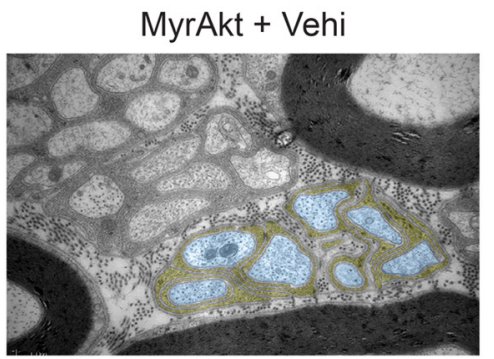

MyrAkt + Rapa
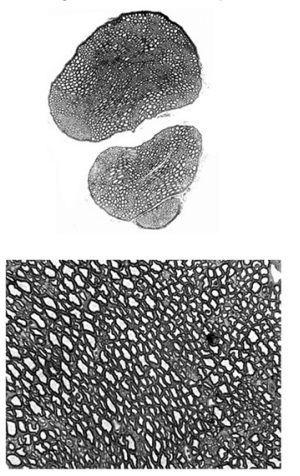

\section{$\gamma$}<smiles>C1CCC1</smiles> 
activation of Racl may account for the hyperwrapping and hypermyelination observed in the PTEN conditional mice given the similarity of phenotypes.

Interestingly, the membrane outfoldings and Schwann cell pockets induced by MyrAkt were not obligately coupled to axonal contact; even collagen fibers were wrapped in the transgenic mice (Fig. 6AII). In normal nerves, Akt is activated initially along the internode, in close apposition to and dependent on NRG on the axon; activated Akt is later detected at the paranodes once compact myelin has formed (Heller et al., 2014). The NRGdependent activation of Akt locally, along the inner turn, thus favors specific wrapping of the apposed axon. In contrast, the widespread activation of Akt along other membranes of the transgenic Schwann cells, likely supports wrapping that is independent of axonal contact. Remarkably, some of the Schwann cell processes lacking axonal contact were surrounded by basal lamina in the transgenics (Fig. $6 A, B$ ). These results suggest that Akt may help transduce the axonal signal that drives production and deposition of extracellular matrix components by Schwann cells (Bunge et al., 1986).

A striking result of this study is that the promyelinating effects of Akt are not correlated to the levels of Krox20, the key transcriptional driver of PNS myelination (Topilko et al., 1994). Thus, induction of MyrAkt in Schwann cell cultures resulted in an increase, with some variability, of myelin protein and mRNA levels, despite a modest reduction in the basal levels of Krox20 (Fig. 3). Conversely, inhibition of Schwann cell Akt by Pf partially arrests ensheathment and nearly completely blocks myelin protein expression but not the upregulation of Oct6 and Krox20 (Fig. 2). In the latter case, partial ensheathment of axons may have been sufficient to upregulate these transcription factors, whereas treatment with LY by completely abolishing ensheathment may have thereby blocked Oct6 and Krox20 expression. Together, these results suggest that changes in myelin mRNA and protein levels resulting from Akt inhibition/activation may not be transcriptionally regulated. Alternative possibilities include an effect of Akt on miRNAs or protein translation. Akt has been implicated in regulating miRNA levels via the FOXO transcription factors and MDM2/p53 activity (Xu and Mo, 2012); FOXO phosphorylation is indeed increased in the MyrAkt mice (E.D.-E.; data not shown), raising the potential of similar regulation of the Schwann cell phenotype via miRNAs (Pereira et al., 2010). In addition, Akt may control myelin protein levels by regulating their turnover and translation. A key role for translational control in myelination was shown by the rescue of myelination in ErbB-deficient Schwann cells via expression of activated Mek1DD, which, in turn, strikingly upregulated protein translation (Sheean et al., 2014). Like the MyrAkt transgenics, sciatic nerves in the activated Mek1 transgenic mice are hypermyelinated, with tomacular defects, and have small-caliber axons that remain unmyelinated (Sheean et al., 2014). This latter result suggests that other signaling pathways downstream of NRG/ErbB activation, including the PLC $\gamma /$ calcineurin/NFATc4 pathway (Kao et al., 2009), are also required for expression of the transcriptional phenotype of myelinating Schwann cells.

As in the PTEN mutants, the MyrAkt transgenics have increased mTORC1 activity, evidenced by increased phosphorylation of S6RP (Fig. 8). mTOR has a key role in Schwann cell myelination (Sherman et al., 2012). In particular, the mTORC1 complex links nutrient availability and cell growth by regulating protein and lipid synthesis (Porstmann et al., 2008; Laplante and Sabatini, 2009; Peterson et al., 2011). Mice deficient in the mTORC1 component raptor have delayed myelination and hypomyelination in the adult due to impaired RXR $\gamma$-SREBPcontrolled lipid biosynthesis (Norrmén et al., 2014); these results place mTORC1, and by implication Akt, as important coordinators of protein translation and lipid synthesis in the myelinating Schwann cells. Rapamycin administration dramatically reduces the pathological features of the MyrAkt transgenics, normalizing the g-ratios, number of axons per area, number of myelin abnormalities, and brain weight (Fig. 9). These results corroborate the beneficial effects of rapamycin in treating dysmyelinating pathologies resulting from deregulation of the PI3K-Akt-mTORC1 axis (Narayanan et al., 2009; Goebbels et al., 2012).

Interestingly, the hyperwrapping phenotype in the transgenics in unmyelinated Schwann cells was not blocked by rapamycin (Fig. 9E), presumably as hyperwrapping is driven by Rac1 and is independent of mTOR. Thus, Akt-induced wrapping and myelin production, although coordinated, are two distinct phenomena driven by independent pathways. Indeed, multiple crucial events of myelination, including morphogenesis (Benninger et al., 2007; Ozçelik et al., 2010), transcriptional activation (Zorick et al., 1996; Jacob et al., 2011), protein and lipid synthesis (Nadra et al., 2008; Norrmén et al., 2014), and metabolic status (Pooya et al., 2014) must all be tightly coordinated during Schwann cell myelination. Akt activation likely contributes to each of these events with the potential exception of Krox20dependent transcriptional events.

In conclusion, we have shown that Akt has a key role in regulating PNS myelination, enhancing membrane wrapping potentially via Racl activation and myelin protein synthesis via mTORC1. These studies suggest that PI3K/Akt activation cooperates with other signaling pathways during the shift from the ensheathing to the myelinating Schwann cell phenotype. Our data additionally suggest that myelin abnormalities in various neuropathies, including infoldings/outfoldings and tomacula, may result from Akt activation and highlight Akt and its effectors, as potential therapeutic targets. Akt activation would be expected to ameliorate the phenotype of hypomyelinating peripheral neuropathies (e.g., CMT4C) (Arnaud et al., 2009; Gouttenoire et al., 2013), whereas Akt inhibition would be a candidate to ameliorate tomacular defects in neuropathies, such as hereditary neuropathy with liability to pressure palsies (Sander et al., 2000; Goebbels et al., 2012). Further studies of Akt-dependent pathways in myelination may identify more specific therapeutic targets for these neuropathies in the future.

\section{References}

Adlkofer K, Frei R, Neuberg DH, Zielasek J, Toyka KV, Suter U (1997) Heterozygous peripheral myelin protein 22-deficient mice are affected by a progressive demyelinating tomaculous neuropathy. J Neurosci 17 : 4662-4671. Medline

Arnaud E, Zenker J, de Preux Charles AS, Stendel C, Roos A, Médard JJ, Tricaud N, Kleine H, Luscher B, Weis J, Suter U, Senderek J, Chrast R (2009) SH3TC2/KIAA1985 protein is required for proper myelination and the integrity of the node of Ranvier in the peripheral nervous system. Proc Natl Acad Sci U S A 106:17528-17533. CrossRef Medline

Benninger Y, Thurnherr T, Pereira JA, Krause S, Wu X, Chrostek-Grashoff A, Herzog D, Nave KA, Franklin RJ, Meijer D, Brakebusch C, Suter U, Relvas JB (2007) Essential and distinct roles for cdc42 and racl in the regulation of Schwann cell biology during peripheral nervous system development. J Cell Biol 177:1051-1061. CrossRef Medline

Bolino A, Bolis A, Previtali SC, Dina G, Bussini S, Dati G, Amadio S, Del Carro U, Mruk DD, Feltri ML, Cheng CY, Quattrini A, Wrabetz L (2004) Disruption of Mtmr2 produces CMT4B1-like neuropathy with myelin outfolding and impaired spermatogenesis. J Cell Biol 167:711-721. CrossRef Medline

Bolis A, Coviello S, Bussini S, Dina G, Pardini C, Previtali SC, Malaguti M, Morana P, Del Carro U, Feltri ML, Quattrini A, Wrabetz L, Bolino A 
(2005) Loss of Mtmr2 phosphatase in Schwann cells but not in motor neurons causes Charcot-Marie-Tooth type 4B1 neuropathy with myelin outfoldings. J Neurosci 25:8567-8577. CrossRef Medline

Bunge RP, Bunge MB, Eldridge CF (1986) Linkage between axonal ensheathment and basal lamina production by Schwann cells. Annu Rev Neurosci 9:305-328. CrossRef Medline

Chandross KJ, Cohen RI, Paras P Jr, Gravel M, Braun PE, Hudson LD (1999) Identification and characterization of early glial progenitors using a transgenic selection strategy. J Neurosci 19:759-774. Medline

Cho H, Thorvaldsen JL, Chu Q, Feng F, Birnbaum MJ (2001a) Akt1/PKBalpha is required for normal growth but dispensable for maintenance of glucose homeostasis in mice. J Biol Chem 276:38349-38352. CrossRef Medline

Cho H, Mu J, Kim JK, Thorvaldsen JL, Chu Q, Crenshaw EB 3rd, Kaestner KH, Bartolomei MS, Shulman GI, Birnbaum MJ (2001b) Insulin resistance and a diabetes mellitus-like syndrome in mice lacking the protein kinase Akt2 (PKB beta). Science 292:1728-1731. CrossRef Medline

Cotter L, Ozçelik M, Jacob C, Pereira JA, Locher V, Baumann R, Relvas JB, Suter U, Tricaud N (2010) Dlg1-PTEN interaction regulates myelin thickness to prevent damaging peripheral nerve overmyelination. Science 328:1415-1418. CrossRef Medline

Decker L, Desmarquet-Trin-Dinh C, Taillebourg E, Ghislain J, Vallat JM, Charnay P (2006) Peripheral myelin maintenance is a dynamic process requiring constant Krox20 expression. J Neurosci 26:9771-9779. CrossRef Medline

Deinhardt K, Kim T, Spellman DS, Mains RE, Eipper BA, Neubert TA, Chao MV, Hempstead BL (2011) Neuronal growth cone retraction relies on proneurotrophin receptor signaling through Rac. Sci Signal 4:ra82. CrossRef Medline

Easton RM, Cho H, Roovers K, Shineman DW, Mizrahi M, Forman MS, Lee VM, Szabolcs M, de Jong R, Oltersdorf T, Ludwig T, Efstratiadis A, Birnbaum MJ (2005) Role for Akt3/protein kinase Bgamma in attainment of normal brain size. Mol Cell Biol 25:1869-1878. CrossRef Medline

Ebi H, Costa C, Faber AC, Nishtala M, Kotani H, Juric D, Della Pelle P, Song Y, Yano S, Mino-Kenudson M, Benes CH, Engelman JA (2013) PI3K regulates MEK/ERK signaling in breast cancer via the Rac-GEF, P-Rexl. Proc Natl Acad Sci U S A 110:21124-21129. CrossRef Medline

Flores AI, Narayanan SP, Morse EN, Shick HE, Yin X, Kidd G, Avila RL, Kirschner DA, Macklin WB (2008) Constitutively active Akt induces enhanced myelination in the CNS. J Neurosci 28:7174-7183. CrossRef Medline

Franke TF (2008) PI3K/Akt: getting it right matters. Oncogene 27:64736488. CrossRef Medline

Franke TF, Yang SI, Chan TO, Datta K, Kazlauskas A, Morrison DK, Kaplan DR, Tsichlis PN (1995) The protein kinase encoded by the Akt protooncogene is a target of the PDGF-activated phosphatidylinositol 3-kinase. Cell 81:727-736. CrossRef Medline

Gills JJ, Dennis PA (2009) Perifosine: update on a novel Akt inhibitor. Curr Oncol Rep 11:102-110. CrossRef Medline

Goebbels S, Oltrogge JH, Kemper R, Heilmann I, Bormuth I, Wolfer S, Wichert SP, Möbius W, Liu X, Lappe-Siefke C, Rossner MJ, Groszer M, Suter U, Frahm J, Boretius S, Nave KA (2010) Elevated phosphatidylinositol 3,4,5-trisphosphate in glia triggers cell-autonomous membrane wrapping and myelination. J Neurosci 30:8953-8964. CrossRef Medline

Goebbels S, Oltrogge JH, Wolfer S, Wieser GL, Nientiedt T, Pieper A, Ruhwedel T, Groszer M, Sereda MW, Nave KA (2012) Genetic disruption of Pten in a novel mouse model of tomaculous neuropathy. EMBO Mol Med 4:486-499. CrossRef Medline

Gouttenoire EA, Lupo V, Calpena E, Bartesaghi L, Schüpfer F, Médard JJ, Maurer F, Beckmann JS, Senderek J, Palau F, Espinós C, Chrast R (2013) Sh3tc2 deficiency affects neuregulin-1/ErbB signaling. Glia 61: 1041-1051. CrossRef Medline

Gravel M, Di Polo A, Valera PB, Braun PE (1998) Four-kilobase sequence of the mouse CNP gene directs spatial and temporal expression of lacZ in transgenic mice. J Neurosci Res 53:393-404. CrossRef Medline

Heller BA, Ghidinelli M, Voelkl J, Einheber S, Smith R, Grund E, Morahan G, Chandler D, Kalaydjieva L, Giancotti F, King RH, Fejes-Toth AN, FejesToth G, Feltri ML, Lang F, Salzer JL (2014) Functionally distinct PI 3-kinase pathways regulate myelination in the peripheral nervous system. J Cell Biol 204:1219-1236. CrossRef Medline

Hennessy BT, Lu Y, Poradosu E, Yu Q, Yu S, Hall H, Carey MS, Ravoori M, Gonzalez-Angulo AM, Birch R, Henderson IC, Kundra V, Mills GB
(2007) Pharmacodynamic markers of perifosine efficacy. Clin Cancer Res 13:7421-7431. CrossRef Medline

Innocenti M, Frittoli E, Ponzanelli I, Falck JR, Brachmann SM, Di Fiore PP, Scita G (2003) Phosphoinositide 3-kinase activates Rac by entering in a complex with Eps8, Abi1, and Sos-1. J Cell Biol 160:17-23. CrossRef Medline

Jacob C, Christen CN, Pereira JA, Somandin C, Baggiolini A, Lötscher P, Ozçelik M, Tricaud N, Meijer D, Yamaguchi T, Matthias P, Suter U (2011) HDAC1 and HDAC2 control the transcriptional program of myelination and the survival of Schwann cells. Nat Neurosci 14:429-436. CrossRef Medline

Kao SC, Wu H, Xie J, Chang CP, Ranish JA, Graef IA, Crabtree GR (2009) Calcineurin/NFAT signaling is required for neuregulin-regulated Schwann cell differentiation. Science 323:651-654. CrossRef Medline

Kidd GJ, Ohno N, Trapp BD (2013) Biology of Schwann cells. Handb Clin Neurol 115:55-79. CrossRef Medline

Laplante M, Sabatini DM (2009) mTOR signaling at a glance. J Cell Sci 122:3589-3594. CrossRef Medline

Leavens KF, Easton RM, Shulman GI, Previs SF, Birnbaum MJ (2009) Akt2 is required for hepatic lipid accumulation in models of insulin resistance. Cell Metab 10:405-418. CrossRef Medline

Matsui T, Li L, del Monte F, Fukui Y, Franke TF, Hajjar RJ, Rosenzweig A (1999) Adenoviral gene transfer of activated phosphatidylinositol 3'kinase and Akt inhibits apoptosis of hypoxic cardiomyocytes in vitro. Circulation 100:2373-2379. CrossRef Medline

Maurel P, Salzer JL (2000) Axonal regulation of Schwann cell proliferation and survival and the initial events of myelination requires PI 3-kinase activity. J Neurosci 20:4635-4645. Medline

Michailov GV, Sereda MW, Brinkmann BG, Fischer TM, Haug B, Birchmeier C, Role L, Lai C, Schwab MH, Nave KA (2004) Axonal neuregulin-1 regulates myelin sheath thickness. Science 304:700-703. CrossRef Medline

Mirsky R, Woodhoo A, Parkinson DB, Arthur-Farraj P, Bhaskaran A, Jessen KR (2008) Novel signals controlling embryonic Schwann cell development, myelination and dedifferentiation. J Peripher Nerv Syst 13: 122-135. CrossRef Medline

Monk KR, Feltri ML, Taveggia C (2015) New insights on Schwann cell development. Glia 63:1376-1393. CrossRef Medline

Nadra K, de Preux Charles AS, Médard JJ, Hendriks WT, Han GS, Grès S, Carman GM, Saulnier-Blache JS, Verheijen MH, Chrast R (2008) Phosphatidic acid mediates demyelination in Lpin 1 mutant mice. Genes Dev 22:1647-1661. CrossRef Medline

Narayanan SP, Flores AI, Wang F, Macklin WB (2009) Akt signals through the mammalian target of rapamycin pathway to regulate CNS myelination. J Neurosci 29:6860-6870. CrossRef Medline

Nave KA, Salzer JL (2006) Axonal regulation of myelination by neuregulin 1. Curr Opin Neurobiol 16:492-500. CrossRef Medline

Nave KA, Werner HB (2014) Myelination of the nervous system: mechanisms and functions. Annu Rev Cell Dev Biol 30:503-533. CrossRef Medline

Newbern J, Birchmeier C (2010) Nrg1/ErbB signaling networks in Schwann cell development and myelination. Semin Cell Dev Biol 21:922-928. CrossRef Medline

Nodari A, Zambroni D, Quattrini A, Court FA, D’Urso A, Recchia A, Tybulewicz VL, Wrabetz L, Feltri ML (2007) Betal integrin activates Rac1 in Schwann cells to generate radial lamellae during axonal sorting and myelination. J Cell Biol 177:1063-1075. CrossRef Medline

Norrmén C, Figlia G, Lebrun-Julien F, Pereira JA, Trötzmüller M, Köfeler HC,Rantanen V, Wessig C, van Deijk AL, Smit AB, Verheijen MH, Rüegg MA, Hall MN, Suter U (2014) mTORC1 controls PNS myelination along the mTORC1-RXRgamma-SREBP-lipid biosynthesis axis in Schwann cells. Cell Rep 9:646-660. CrossRef Medline

Noseda R, Belin S, Piguet F, Vaccari I, Scarlino S, Brambilla P, Martinelli Boneschi F, Feltri ML, Wrabetz L, Quattrini A, Feinstein E, Huganir RL, Bolino A (2013) DDIT4/REDD1/RTP801 is a novel negative regulator of Schwann cell myelination. J Neurosci 33:15295-15305. CrossRef Medline

Ogata T, Iijima S, Hoshikawa S, Miura T, Yamamoto S, Oda H, Nakamura K, Tanaka S (2004) Opposing extracellular signal-regulated kinase and Akt pathways control Schwann cell myelination. J Neurosci 24:6724-6732. CrossRef Medline

Ozçelik M, Cotter L, Jacob C, Pereira JA, Relvas JB, Suter U, Tricaud N 
(2010) Pals1 is a major regulator of the epithelial-like polarization and the extension of the myelin sheath in peripheral nerves. J Neurosci 30: 4120-4131. CrossRef Medline

Patzig J, Jahn O, Tenzer S, Wichert SP, de Monasterio-Schrader P, Rosfa S, Kuharev J, Yan K, Bormuth I, Bremer J, Aguzzi A, Orfaniotou F, Hesse D, Schwab MH, Möbius W, Nave KA, Werner HB (2011) Quantitative and integrative proteome analysis of peripheral nerve myelin identifies novel myelin proteins and candidate neuropathy loci. J Neurosci 31:1636916386. CrossRef Medline

Pereira JA, Baumann R, Norrmén C, Somandin C, Miehe M, Jacob C, Lühmann T, Hall-Bozic H, Mantei N, Meijer D, Suter U (2010) Dicer in Schwann cells is required for myelination and axonal integrity. J Neurosci 30:6763-6775. CrossRef Medline

Pereira JA, Lebrun-Julien F, Suter U (2012) Molecular mechanisms regulating myelination in the peripheral nervous system. Trends Neurosci 35: 123-134. CrossRef Medline

Peterson TR, Sengupta SS, Harris TE, Carmack AE, Kang SA, Balderas E, Guertin DA, Madden KL, Carpenter AE, Finck BN, Sabatini DM (2011) mTOR complex 1 regulates lipin 1 localization to control the SREBP pathway. Cell 146:408-420. CrossRef Medline

Pooya S, Liu X, Kumar VB, Anderson J, Imai F, Zhang W, Ciraolo G, Ratner N, Setchell KD, Yoshida Y,Yutaka Y, Jankowski MP, Dasgupta B (2014) The tumour suppressor LKB1 regulates myelination through mitochondrial metabolism. Nat Commun 5:4993. CrossRef Medline

Porstmann T, Santos CR, Griffiths B, Cully M, Wu M, Leevers S, Griffiths JR, Chung YL, Schulze A (2008) SREBP activity is regulated by mTORC1 and contributes to Akt-dependent cell growth. Cell Metab 8:224-236. CrossRef Medline

Robinson FL, Niesman IR, Beiswenger KK, Dixon JE (2008) Loss of the inactive myotubularin-related phosphatase Mtmr13 leads to a CharcotMarie-Tooth 4B2-like peripheral neuropathy in mice. Proc Natl Acad Sci U S A 105:4916-4921. CrossRef Medline

Salzer JL (2015) Schwann cell myelination. Cold Spring Harbor Perspect Biol 7:a020529. CrossRef Medline

Sander S, Ouvrier RA, McLeod JG, Nicholson GA, Pollard JD (2000) Clinical syndromes associated with tomacula or myelin swellings in sural nerve biopsies. J Neurol Neurosurg Psychiatry 68:483-488. CrossRef Medline

Sheean ME, McShane E, Cheret C, Walcher J, Müller T, Wulf-Goldenberg A, Hoelper S, Garratt AN, Krüger M, Rajewsky K, Meijer D, Birchmeier W, Lewin GR, Selbach M, Birchmeier C (2014) Activation of MAPK overrides the termination of myelin growth and replaces Nrg1/ErbB3 signals during Schwann cell development and myelination. Genes Dev 28: 290-303. CrossRef Medline
Sherman DL, Krols M, Wu LM, Grove M, Nave KA, Gangloff YG, Brophy PJ (2012) Arrest of myelination and reduced axon growth when Schwann cells lack mTOR. J Neurosci 32:1817-1825. CrossRef Medline

Snaidero N, Möbius W, Czopka T, Hekking LH, Mathisen C, Verkleij D, Goebbels S, Edgar J, Merkler D, Lyons DA, Nave KA, Simons M (2014) Myelin membrane wrapping of CNS axons by PI(3,4,5)P3-dependent polarized growth at the inner tongue. Cell 156:277-290. CrossRef Medline

Taveggia C, Zanazzi G, Petrylak A, Yano H, Rosenbluth J, Einheber S, Xu X, Esper RM, Loeb JA, Shrager P, Chao MV, Falls DL, Role L, Salzer JL (2005) Neuregulin-1 type III determines the ensheathment fate of axons. Neuron 47:681-694. CrossRef Medline

Tersar K, Boentert M, Berger P, Bonneick S, Wessig C, Toyka KV, Young P, Suter U (2007) Mtmr13/Sbf2-deficient mice: an animal model for CMT4B2. Hum Mol Genet 16:2991-3001. CrossRef Medline

Thurnherr T, Benninger Y, Wu X, Chrostek A, Krause SM, Nave KA, Franklin RJ, Brakebusch C, Suter U, Relvas JB (2006) Cdc42 and Rac1 signaling are both required for and act synergistically in the correct formation of myelin sheaths in the CNS. J Neurosci 26:10110-10119. CrossRef Medline

Topilko P, Schneider-Maunoury S, Levi G, Baron-Van Evercooren A, Chennoufi AB, Seitanidou T, Babinet C, Charnay P (1994) Krox-20 controls myelination in the peripheral nervous system. Nature 371:796-799. CrossRef Medline

Tschopp O, Yang ZZ, Brodbeck D, Dummler BA, Hemmings-Mieszczak M, Watanabe T, Michaelis T, Frahm J, Hemmings BA (2005) Essential role of protein kinase B gamma (PKB gamma/Akt3) in postnatal brain development but not in glucose homeostasis. Development 132:2943-2954. CrossRef Medline

Vlahos CJ, Matter WF, Hui KY, Brown RF (1994) A specific inhibitor of phosphatidylinositol 3-kinase, 2-(4-morpholinyl)-8-phenyl-4H-1benzopyran-4-one (LY294002). J Biol Chem 269:5241-5248. Medline

Xu M, Mo YY (2012) The Akt-associated microRNAs. Cell Mol Life Sci 69:3601-3612. CrossRef Medline

Zanazzi G, Einheber S, Westreich R, Hannocks MJ, Bedell-Hogan D, Marchionni MA, Salzer JL (2001) Glial growth factor/neuregulin inhibits Schwann cell myelination and induces demyelination. J Cell Biol 152: 1289-1299. CrossRef Medline

Zorick TS, Syroid DE, Arroyo E, Scherer SS, Lemke G (1996) The transcription factors SCIP and Krox-20 mark distinct stages and cell fates in Schwann cell differentiation. Mol Cell Neurosci 8:129-145. CrossRef Medline 